This is the accepted manuscript of the article, which has been published in Critical Perspectives on Accounting, 2020, 69, 102088. https://doi.org/10.1016/j.cpa.2019.06.002

(c) 2020. This manuscript version is made available under the CC-BY-NC-ND 4.0 license

\title{
The discursive legitimation of profit in public-private service delivery
}

Peeter Peda, University of Turku, Department of Accounting and Finance, Rehtorinpellonkatu 3, Fl-20500 Turku, Finland. Email: firstname.lastname@utu.fi

Eija Vinnari (corresponding author), Tampere University, Faculty of M anagement and Business, FI-33014 Tampere, Finland. Email: firstname.lastname@tuni.fi

\begin{abstract}
Public-private partnerships are a topic of continuing interest for accounting researchers. However, as yet there are only a few studies focusing on the post-implementation phase of PPPs. In particular, even though scholars have criticized PPPs for inflating the profits of private partners at the expense of the public sector and citizens, they have rarely scrutinized the public debates whereby the legitimacy of PPP organizations' profits are societally contested and debated. The purpose of this article is to shed light on the processes of profit (de)legitimation by examining the construction of senses of (il)legitimacy in public-private service delivery. These processes are examined in the case of Tallinn Water, an Estonian public-private water company. Our findings suggest that the main themes debated revolved around the following questions: What is a normal profit for a public-private monopoly? Who or what is the ultimate authority in such matters? What is morally appropriate behaviour for such a company? Our findings also indicate that even relatively affordable prices and high performance levels do not suffice to create legitimacy for an organization that tries to make excessive gains from the provision of something that is generally regarded as a human right.
\end{abstract}

Keywords: discourse; legitimation; profit; public-private partnership; water sector

\section{Introduction}

This paper is concerned with the discursive legitimation of profit in the context of public-private partnerships (PPPs), and the motivation for it can be derived from several perspectives. First, the burgeoning accounting literature on PPPs has largely focused on issues related to the pre-implementation phase. Such studies have examined for instance the drivers of PPPs (Asenova \& Beck, 2010; Broadbent \& Laughlin, 2005; English and Guthrie, 2003); the calculative methods utilized in ex ante assessments of the costs and benefits of PPP projects (Heald \& Georgiou, 2011; Khadaroo, 2008; Shaoul, 2005); the identification and management of PPP risks (Broadbent, Gill \& Laughlin, 2008; Burke \& Demirag, 2015; Froud, 2003); the (dis)merits of PPPs (Acerete, Stafford \& Stapleton, 2011; Demirag et al., 2012; Shaoul, 
Stafford \& Stapleton, 2008); accounting regulation related to PPPs (Benito, M ontesinos \& Bastida, 2008; Stafford, Acerete $\&$ Stapleton, 2010; Toms, Beck \& Asenova, 2011); as well as issues related to transparency and accountability (Agyanim-Boateng, Stafford \& Stapleton, 2017; Broadbent \& Laughlin, 2003a; Shaoul, Stafford \& Stapleton, 2010, 2012).

Yet, as also two recent reviews (Andon, 2012; Hodge \& Greve, 2018) have pointed out, there is very little research on the operation of PPPs post-implementation. An interesting aspect in this sense relates to the legitimacy of PPPs as a hybrid form of organization (M iller, Kurunmäki \& O'Leary, 2008) where the clashing of business imperatives and the public service ethos are bound to give rise to tensions (Broadbent $\&$ Laughlin, 2003b). Compared to other forms of public service delivery (e.g. direct government delivery or delivery by a fully publicly owned company), the high level of contractual complexity, the dual role of the public partner and diminished public/social accountability can make it relatively challenging for PPPs to gain legitimacy in the eyes of citizens (Hodge $\&$ Greve, 2018). From the perspective of both the private and the public sector parties, a key challenge is arriving at a consensus over what constitutes a legitimate profit for such an undertaking. Based on financial analyses, accounting scholars have criticized PPPs for being unfavorable to the public sector and taxpayers, but they have rarely scrutinized the public debates associated with these issues. At least we are not aware of prior PPP studies that would have explored how the legitimacy of a public-private organization's profit is societally negotiated.

The second motivation for our study is the observation that prior accounting research on legitimation (e.g. Andon, Free \& Sivabalan, 2014; Cho, 2009; O'Dwyer, Owen \& Unerman, 2011) tends to assume a unidirectional relationship between the active organization and various passive audiences, with little attention given to stakeholder attempts at de-legitimation. In other words, such studies appear to have largely ignored the interactive, discursive dimension of legitimation, which is a somewhat curious omission considering that on a conceptual level, acts of legitimation are 'virtually always' discursive (Rojo \& van Dijk, 1997, p. 527; Vaara \& Tienari, 2008). M oreover, being largely informed by institutional perspectives, such studies have given scant consideration to the antagonisms involved in legitimation. Thus, accounting research still lacks an understanding of the discursive, conflictual aspects of legitimation struggles, both in general (Tregidga et al., 2012) and in the particular context of PPPs.

Third, from an empirical perspective, previous accounting studies on PPPs have predominantly analysed empirical events in the UK and Australia, resulting in a lacuna of information concerning PPP arrangements in non-Anglo jurisdictions (Andon, 2012).

The purpose of this paper is to begin addressing these gaps in extant knowledge by shedding more light on the discursive processes of profit (de)legitimation in the context of PPPs. Our main research question is formulated as follows: How is the (il)legitimacy of profit socially constructed during communicative interactions between a public-private organization and various constituencies ${ }^{1}$ ? This broad question can be further divided into two sub-questions: Which topics or themes emerge as particularly salient in the debates concerning the legitimacy of a public-private organization's profit? Which textual means are utilized, and how, to represent a certain level of profit as (in)appropriate for a PPP? To shed light on these issues, we will employ critical discourse analysis, in particular the discursive strategies of legitimation framework developed by van Leeuwen (1996) and further refined by Vaara, Tienari \& Laurila (2006). This

\footnotetext{
${ }^{1}$ We use 'constituencies' instead of the rather anodyne term 'stakeholders' as the latter is often associated with a neo-pluralist approach that effectively glosses over power differentials and conflict (see Brown, 2017).
} 
framework is suitable for our examination as it focuses particularly on the political aspects of legitimation in the case of societally controversial organizational actions (Vaara \& Tienari, 2008). Our basic assumption is that legitimation is a dynamic, conflictual process (M oll \& Hoque, 2011) whereby diverse counterhegemonic groups contest the legitimacy of a dominant organization's actions.

Due to the ambiguous nature of water services (see subsection 3.1), a public-private water company can be considered an example of the most likely case to result in a societal conflict over legitimacy. Thus, we examine these issues in the context of Tallinn Water (TW), a stock-listed Estonian water company whose main shareholders are a multinational water firm and the City of Tallinn. In the literature, a number of PPP classifications can be found based on their purpose and various dimensions. Tallinn Water represents a specific form of PPPs called mixed companies with public-private ownership, which the European Commission refers to as institutionalized PPPs (da Cruz and M arques, 2012). It is thus different from a form of PPP called DBFO (design-build-finance-operate), which is the focus of much Anglophone literature on the topic. Our empirical material, which covers the period 2008-2012, consists of over 600 text documents such as newspaper articles, press releases, stock announcements, legislation, blog texts, and so forth.

We believe our study to make three contributions to prior accounting research. First, we complement extant knowledge on PPPs by focusing on the accounting-related tensions stemming from the hybrid nature of PPP organizations. More specifically, we identify and analyse the key issues debated in the context of the wider question of a public-private organization's profit. We also identify and analyse the strategies that the focal company as well as the most vocal counter-hegemonic groups employ to (de)legitimate the profit. Second, we illustrate the applicability of the discursive strategies of legitimation framework (van Leeuwen, 1996; Vaara et al., 2006) to the study of legitimation struggles associated with accounting constructs, in this case profit. Third, we respond to Andon's (2012) as well as Hodge and Greve's (2018) calls by offering a theoretically informed PPP analysis situated in a thus far neglected geographical context, namely Estonia.

The paper proceeds as follows. The next section reviews prior accounting research on PPPs and introduces the critical discourse analytical approach to the study of legitimation struggles. This is followed by an elaboration of the specific issues related to profit-making in water services as well as the introduction to the case context, data and method of analysis. The subsequent section analyses the empirical data in light of the theoretical framework. The final section discusses the findings in light of prior research and contains the authors' conclusions and suggestions for future research.

\section{Literature review}

\subsection{Critical research on public-private partnerships}

Although PPPs have a long and diverse history (see e.g. Weihe, 2008), they truly began to gain international attention in 1992 when the UK government introduced the Private Finance Initiative (PFI), which is currently categorized as a subset of PPP undertakings. The UK example quickly diffused to other AngloAmerican countries and is currently spreading across globe, often promoted by international organizations such as the Organization for Economic Cooperation and Development (OECD), the World Bank and the Association of South East Asian Nations (ASEAN) (Hodge \& Greve, 2018). In the past almost three decades, research on PPPs has proliferated to cover a variety of themes, such as the drivers of PPPs; methods for ex ante evaluation of costs, benefits, and risks; associated accounting regulation; pros and cons of PPPs; as 
well as problems of transparency and accountability (see Andon, 2012; Hodge \& Greve, 2018). In what follows, we will briefly review studies and themes we deem to be most relevant for present purposes.

One stream of PPP research is constituted by studies that focus on the motivations for PPPs. The major publicly cited reasons for PPPs include the transfer of risk from to the public to the private sector as well as governments being able to provide services without increasing public debt. In addition to these overt justifications, it has been argued especially in the early studies that a major driver of PPPs is governments' neoliberal privatization agenda (Broadbent \& Laughlin, 2005; English \& Guthrie, 2003; Newberry \& Pallot, 2003). Broadbent, Gill \& Laughlin (2004) for instance suggest that, in the UK context, the justifications for PFI have oscillated over time between the need to close the infrastructure investment gap without increasing public expenditure, and the need to obtain value for money and risk transfer. M ore recently, other key factors driving PPPs have also been identified. Asenova and Beck (2010) for instance foreground the role of financing institutions' risk considerations in PFI schemes. These authors begin from the assumption that PFI schemes are less attributable to the cash-strapped public sector's wish to find a way to provide services than they are to the financing sector's preference for long-term, low-risk investment opportunities to balance portfolios. Based on interviews and documentary evidence, Asenova and Beck (2010) claim that PFI deals are contingent upon financers' risk-return requirements derived from associated models and procedures that remain opaque to other stakeholders, thus undermining aspirations towards accountability. Further, as the dominant parties of PFI projects, finance providers are able to define what constitutes a viable project and which requirements the contracting parties must undertake to meet with the financers' approval.

A second stream of PPP research comprises critical assessments of the methods utilized in ex ante evaluation of the costs and benefits of PPP projects. Shaoul (2005) for instance offers a critical analysis of the distributional effects of PFI in the UK National Health Service by examining the PFI process, the accounting methodology utilized in appraising the PFI arrangement, and the ex ante Value for M oney (VFM ) analysis conducted by the UK Government. As a result of her exploratory study, Shaoul (2005) finds that contrary to purported effects of increased rationality and VFM, the PFI related decision-making was replete with interventions of political actors who sought first and foremost to promote private sector involvement. She forecasts that the ultimate result of the PFI in the UK will be an inequitable transfer of wealth from the less well-off to a few select private sector companies. Shaoul's (2005) findings are supported by Khadaroo's (2008) analysis of how PFI bids are evaluated on the level of organizations in general and in the case of three Northern Ireland schools in particular. Based on qualitative interviews with school representatives, Khadaroo (2008) draws the conclusion that the financial benefits of the PFI arrangements in question were marginal, the non-financial criteria and weightings given to them were subjective, and the implementation of PFI was politically determined. Benito, M ontesinos and Bastida (2008) in turn review PFI-related proposals in the Spanish context. These authors argue that deficiencies in associated accounting regulations enable the government to practice 'creative accounting' via PFIs. In particular, Benito et al. (2008) claim, the government is able to utilize such arrangements to enable continued investments in infrastructure while avoiding the accumulation of debt on the balance sheet.

A third, albeit considerably smaller, stream of critical PPP research has focused on PPPs postimplementation. Shaoul's (1997) financial analysis of the fully privatized water companies in England and Wales indicates that not only did the purported efficiency gains not materialize but also consumer prices for water services rose by 50 per cent. Moreover, Shaoul (1997) argues, the requirement to pay dividends 
to the water companies' new shareholders disadvantaged both present and future consumers, citizens and taxpayers. To illustrate, six years after the privatization, the average return on the ten largest water companies in the UK was 94 per cent, while the corresponding return on the FTSE100 index was 35 per cent (Shaoul, 1997, p. 499). Another post-implementation analysis is provided by Toms, Beck and Asenova (2011), who take a critical look at PFI refinancing, in other words post-implementation changes in interest rates, repayment dates, margins and other financial parameters of the debt taken to finance PFI projects. Toms et al. (2011) show that in the UK, refinancing has more often than not resulted in multiplying the financial profits of the private partners, in some extreme cases resulting in rates of return of over 70 per cent $^{2}$. M eanwhile, corresponding gains to the state have materialized to a considerably lesser extent due to bureaucratic institutions' unwillingness to tighten regulation in the fear of private organizations losing interest in bidding for PFI deals. Acerete, Stafford and Stapleton (2011) undertake an evaluation of a Spanish hospital PPP arrangement, which involved the negotiation of several service contracts. Based on empirical evidence gathered from publicly available documents, Acerete et al. (2011) show that under the terms of the first service contract, the project could not have even been financially viable and that the renegotiation of the contract has proved costly to the Spanish government.

In broad terms, scholars recognized early on that PPPs can be conceptualized as organizational hybrids (M iller et al., 2008) where the public service ethos clashes with private sector profitability aspirations (Broadbent \& Laughlin, 2003b). Shaoul, Stafford and Stapleton (2012) note how these fundamental differences give rise to tensions between the private sector's arguably narrow corporate governance logic and the public sector's more complex accountability regime in the context of PPPs. In their study, Shaoul et al. (2012) focus on the role of financial disclosures in meeting the information needs of the multiple stakeholders and especially in discharging accountability to citizens. They note that PPPs pose accountability-related challenges due to the long time horizon of the projects, the complex relationships between multiple and changing partners, the lack of a clear division of responsibilities among the partners as well as contracts that are often difficult to enforce.

Although the studies reviewed above have greatly enhanced our understanding of the diverse problems associated with PPPs, particularly in terms of illuminating how private partners often gain excessive financial profits from the arrangements, very few studies have examined public debates on these issues. At least we are not aware of prior accounting studies, or public management studies, that would have explored how the legitimacy of a public-private organization's profit is societally negotiated. Our approach for undertaking such an investigation is elaborated in the next section.

\subsection{A discursive perspective on legitimation struggles}

The sociologically oriented legitimacy literature focuses on beliefs about what is considered appropriate. This literature often defines legitimacy along the same lines as Suchman (1995, p. 574): 'a generalized perception or assumption that the actions of an entity are desirable, proper, or appropriate within some socially constructed system of norms, values, beliefs, and definitions'. In other words, the legitimacy necessary for organizational survival (Dowling \& Pfeffer, 1975; O'Donovan, 2002; Suddaby \& Greenwood, $2005)$ is considered to be based on societal perceptions of an entity rather than on its actual conduct.

\footnotetext{
${ }^{2}$ In a paper that mainly focuses on the UK National Audit Office, Smyth and Whitfield (2017) touch upon excessive profit-making in the context of PPPs by illustrating how primary equity investors benefited from windfall gains when selling their equity shares soon after the PPP assets were delivered.
} 
Legitimacy is closely related to power in the sense that it is organizational stakeholders who wield legitimacy-determining power (Dowling and Pfeffer, 1975). Furthermore, stakeholders' senses of legitimacy can rest on different bases - such as the moral (normative approval), the pragmatic (self-interest), and the cognitive (taken-for-grantedness) bases - when organizations develop and apply various strategies for gaining, maintaining, and repairing legitimacy (Suchman, 1995; Woodward et al., 1996).

The sociological approach to the study of legitimation is quite common in the accounting literature (see e.g. Andon et al., 2014; Cho, 2009; O'Dwyer, Owen \& Unerman, 2011). However, these studies tend to assume a unidirectional relationship between the active organization and various passive audiences, thereby neglecting to consider that legitimation is a dynamic, often conflictual process (M oll \& Hoque, 2011) where diverse constituencies react in different ways to organizational attempts to construct legitimacy. M oreover, these studies are often informed by institutional perspectives, which are arguably ill-equipped to deal with antagonism or to promote emancipation (Clegg, 2010; Zald \& Lounsbury, 2010; Dillard, Rigsby \& Goodman, 2004; Spence, Husillos \& Correa, 2010; for a discussion see M odell, 2015). This suggests to us that accounting research is in need of further analytical tools for the critical scrutiny of the interactive, discursive dimension of legitimation conflicts. Such tools are provided by critical discourse analysis and especially the discursive strategies of legitimation framework, which form the subject matter of the remainder of this section.

Ever since social sciences took the linguistic turn (Alvesson and Kärreman, 2000), management and accounting scholars have taken an interest in analyzing organizational discourses. 'Discourse' is a widely applied, ambiguous concept that can be understood in a variety of ways, ranging from local and situational use of language in social practices to more abstract, macro-level "mega discourses" (Alvesson \& Kärreman, 2011). Fairclough (1992) for instance sees any instance of discourse as comprising three dimensions: a piece of text itself, the processes of its production and interpretation as well as the associated institutional and organizational circumstances. Texts in this context are understood in a wide sense, as 'oral, written and even gestural texts' (Putnam \& Cooren, 2004), written documents, speech acts, pictures and symbols (Grant et al., 1998).

Regardless of the definition of discourse employed, the wide variety of approaches and methods that are currently categorized under the label of discourse analysis are united by their interest in the way that discourse constructs organizational and social life, rather than simply reflecting it (Hardy et al., 2005). In other words, social objects and phenomena are viewed as being constructed through the production and dissemination of various types of texts, instead of language describing a reality existing 'out there' independently of our observation. However, the different approaches vary with regard to the extent to which they consider discourse to be 'muscular' (Alvesson \& Kärreman, 2011), that is, capable of changing the social world. Laclau and M ouffe's (1985) discourse theory for instance views discourse as fully constitutive of reality, while critical discourse analysis (CDA) considers reality to be shaped by both discourses and non-discursive elements (Jørgensen \& Phillips, 2002). According to Phillips and Oswick (2012), discourse analytical approaches have proved most fruitful in the investigation of the emergence, change and disappearance of social constructs such as identity and institution. In the present paper, the social construct to be examined is the legitimacy of a public-private company's profit.

Discourse analysis can be defined as 'analysis of collections of texts, the ways they are made meaningful through their links to other texts, the ways in which they draw on different discourses, how and to whom 
they are disseminated, the methods of their production, and the manner in which they are received and consumed' (Phillips et al., 2004, p. 636). One variant of this methodology is CDA, which attempts to facilitate social emancipation by illustrating how the use of language in a specific socio-historical context contributes to reproducing or challenging relations of power (Wodak \& Meyer, 2009, p. 6). According to Fairclough (2010), CDA is based on a critical realist ontology, in other words, it posits the existence of distinct objectified structures that condition but do not determine human agency, thereby making it possible for agents to emancipate themselves from oppressive structures (Bhaskar, 1975; Archer, 1995; see also M odell, 2015). As pointed out by M erkl-Davies and Koller (2011), CDA's critical realist worldview as well as its interest in power, emancipation and interdisciplinarity make it a good fit with critically oriented accounting research.

CDA is useful for the purposes of the present paper as it facilitates our understanding of socio-political and ideological aspects of legitimacy (Joutsenvirta \& Vaara, 2015). From a CDA perspective, legitimation draws on discourses (Vaara, 2014), which in turn are constitutive of ideologies such as neoliberalism (Bourdieu \& Wacquant, 2001) or nationalism (Wodak et al., 1999). CDA investigates the ways in which legitimacy is constructed, either consciously or unconsciously, through micro-level textual practices and strategies (Fairclough, 2003; Vaara, 2014). In other words, the focus of CDA is on legitimizing discourses through which certain actions are presented as beneficial and morally or politically defensible, whereas others are described as being morally reprehensible or otherwise unacceptable (Rojo \& van Dijk, 1997).

The CDA framework mobilized in this paper is the grammar of legitimation developed by van Leeuwen (1996) and comprising four discursive strategies of legitimation: authorization, rationalization, moral evaluation and mythopoesis. Vaara et al. (2006) refined this framework by adding a fifth strategy, namely normalization, which in van Leeuwen's original framework is included in the authorization category. Normalization as a strategy refers to legitimation by reference to the normality of functions or behaviour, in the spirit of 'everybody does it' or 'everybody says so' (van Leeuwen and Wodak, 1999, p. 105). It is an attempt to naturalize specific action by exemplification, by referring to similar events, cases or practices that have taken place in the past (retrospectively) or that are expected to take place in the future (prospectively). Authorization refers to legitimation by appeal to the authority of institutions such as legislation, conventions and traditions, or the institutionalized authority of a specific actor. Rationalization refers to legitimation by appeal to the function or utility that particular actions or practices serve (institutional rationalization) or to the 'facts of life' (theoretical rationalization) (van Leeuwen and Wodak, 1999, p. 105). In the case of instrumental rationalization, an activity is presented as being a method or a necessity for the achievement of certain moral objectives, whereas in the case of de-legitimation an activity is presented as an obstacle to the achievement of moral targets. Theoretical rationalization legitimates activities by implying that they are done because 'that is the way things are' or 'that is the way [people] are' (van Leeuwen \& Wodak, 1999, p. 107). Here it is important to note that rationalization cannot be decoupled from moral and ideological foundations; these are just latent in the seemingly common-sense argumentation.

M oralization as the fourth distinct strategy of legitimation differs from rationalization in that its appeal to particular values is explicit. With this strategy, the aim is to gain normative approval for a construct or action by showing that it is consistent with a generally accepted moral order (Rojo \& van Dijk, 1997). The two forms of moralization are moral abstraction, which relates particular activities to particular values through seemingly straightforward description; and outright moral evaluation, in which the moral position 
is clearly articulated. Finally, narrativization or mythopoesis refers to legitimation through telling stories that contain a normative undertone, explaining how to act in an appropriate or acceptable fashion. These stories often suggest that something good may happen to a heroic actor who follows legitimate practices (moral tales) or that something bad may take place if socially appropriate action is not taken (cautionary tales) (van Leeuwen \& Wodak, 1999). Such narratives are often written in an entertaining tone (Vaara et al., 2006).

We maintain that the five discursive strategies of legitimation framework is particularly suitable for our study for several reasons. First, it helps us avoid the main problems of discourse studies identified by Alvesson and Kärreman $(2000,2011)$, namely, using 'discourse' in an all-encompassing manner and taking for granted the 'muscularity' of discourse. Instead of reducing everything into discourse, the strategies of legitimation framework focuses on micro-level textual practices employed in a local and situational context, in our case the public debate in Estonia about the legitimacy of the water company's profitability. Further, and as elaborated in the next section, the framework's definition of 'texts' is also rather concise, being limited to media and other written texts intended for public consumption. As concerns the problem of muscularity, the strategies of legitimation framework does not assume that discourse alone has the power to change social reality. Instead, as the framework focuses on how the legitimacy of things such as profit comes to be represented in competing ways, it rather views language as having the power to frame reality (Alvesson \& Kärreman, 2011, p. 1141). As aptly expressed by Jørgensen and Phillips (2002, p. 9), "different discourses each point to different courses of action as possible and appropriate", and it is through this mechanism that discourses can be considered to have effects on social realities.

Second, we consider the strategies of legitimation framework to have certain benefits compared to other discourse analytical frameworks utilized in critical accounting studies, such as dialogics or Discourse Theory. Dialogics ${ }^{3}$ as a discourse analytical framework draws on the ideas developed by the Bakhtin Circle (see e.g. Bakhtin, 1981; Volosinov, 1973). In critical accounting studies, the Bakhtinian dialogical understanding of language has often been combined with a M arxist view of society (Catchpowle and Cooper, 1999; Catchpowle and Smyth, 2016; Smyth and Whitfield, 2017). These studies have illustrated for instance how a particular word (e.g. 'privatisation') or piece of accounting information can take on different, class-based meanings in specific historical and material contexts, and how struggles over language provide opportunities for marginalized groups to contest dominant groups' monologic interpretations. Discourse Theory (Laclau \& M ouffe, 1985/2001) in turn is a post-structuralist approach, which considers social relations and identities to be (re)produced in the cultural realm instead of being predetermined through a class-base. Discourse Theory has been mobilized in accounting research to identify and critique the discursive means by which business companies and other powerful actors attempt to maintain their hegemonic position in society (Tregidga, Kearins and Milne, 2014) and try to dismiss marginalized groups' counter-hegemonic projects (Laine \& Vinnari, 2017). Thus, both dialogics and Discourse Theory would have been applicable to the study of how Tallinn Water tries to deflect diverse groups' critical commentaries

\footnotetext{
${ }^{3}$ In accounting research, several varieties of 'dialogics' can be distinguished. Inspired by Freire (e.g. 1970, 1985), Bebbington et al. (2007) have proposed dialogic accounting as a way of analyzing and improving the efficacy of social and environmental reporting. Brown (2009) has connected dialogic accounting to M ouffe's (2013) agonistic pluralism which, while celebrating the diversity of perspectives, emphasizes also ineradicable tensions, conflicts and power dynamics (for a review of the wealth of studies inspired by Brown (2009), see Dillard \& Brown, 2015). Here, since our focus is on discourse analytical frameworks, we compare CDA only to the third 'version' of dialogics, namely that inspired by a Bakhtinian understanding of language.
} 
regarding its attempts to reap excessive profits from the provision of a necessity service. However, both of these approaches focus largely on macro-level discourses and as such do not offer concrete advice for undertaking the textual analysis ( ørgensen and Phillips, 2002). Since the study at hand focuses on microlevel linguistic practices, we consider the systematic categorization provided by the strategies of legitimation framework very helpful for our analysis. Yet, precisely because of this focus on linguistic means, the framework needs to be supplemented with more critically loaded concepts such as (counter)hegemony, dominance and power, which we will employ especially in the concluding discussion to highlight the antagonistic nature of the conflict as well as the uneven power distribution between the dominant water company and the critical constituencies.

\section{Context, data and method}

\subsection{Profit making in public-private water services}

A major legitimacy-related concern regarding public-private service provision is the balance between the public (non-financial) and private (financial) benefits that such partnerships produce (Hodge, 2006; Brinkerhoff and Brinkerhoff, 2011). The maximization of financial profit is not usually seen as an objective of public sector organizations (Bouckaert and Halligan, 2008); their performance is considered to deal more with value patterns, such as legality and legitimacy. However, in the context of liberalization, it has been considered necessary to impose certain public service obligations on enterprises operating in infrastructure sectors to ensure a basic level of service delivery and to protect the interests of public service consumers (Finger and Finon, 2011). Thus, efficiency and effectiveness as well as cost recovery and profit considerations remain important in public services, such as water services, in order to ensure their sustainable delivery. Moreover, municipalities as the owners of companies can exhibit interest in profitability in terms of return on capital invested (Grossi and Reichard, 2008).

The nature of water services as a good is ambiguous and debated (Rogers, de Silva \& Bhatia, 2002). Traditionally, water services are conceived of as a public good; however, according to neoclassical economic theory (Samuelson, 1954) water services should be viewed as a private good because water is excludable (individuals who have not paid for it can be prevented from using it) and rivalrous (consumption by one individual decreases the total amount available to others). Water services can also be viewed as a merit good (Musgrave, 1959) and an economic good. The provision of water services is argued to be a merit good because of the public interest (externalities) at stake (Schouten \& Schwartz, 2006). In a United Nations (UN) setting, Principle 4 of the Dublin Statement declares that water 'should be recognized as an economic good' (ICWE, 1992). More recently, the UN Committee on Economic, Cultural and Social Rights (2002) issued a non-binding declaration stating that water is a public good and a human right, and finally, in 2010, the UN General Assembly recognized water services as a basic human right (UN, 2010). A citizens' initiative to implement this recognition in the form of European legislation was approved after a debate in 2014 by the European Union (EU) Commission (Lieberherr \& Fuenfschilling, 2016, p. 1547). These latter developments have brought international political weight behind the idea that national governments around the world must ensure access to safe, clean and affordable drinking water and sanitation services.

Thus, water services can be perceived simultaneously as a private and economic good, a public good, a merit good and a human right. An apparent consequence of the hybrid nature of water services is the 
tension between public-merit and private-economic considerations. While being a merit good and human right implies a central role for the public sector in water services provision (Schouten $\&$ Schwartz, 2006), the properties that make water services a private--economic good present the need for business-like management and financing approaches inherent to the private sector. Striking a balance between these perceptions of water services might be a challenging task but also a very important one, as this perception is likely to influence the social acceptance of public-private companies in water services provision.

From the water users' perspective, the central economic concern related to water services provision is that its natural monopoly characteristics (Parker, 1999) and the resulting imperfect competition may lead to reduced output, relatively higher prices, and wealth transfers from water users to providers (Letza \& Smallman, 2001). Therefore, economic regulation of water services provision is usually considered necessary to protect the public interest (ibid). Shirley and M enard (2002) note that optimal economic regulation provides water companies with the incentive to invest and improve efficiency while funnelling the largest possible share of the resulting savings to water users. Nevertheless, Kinnunen (2005) emphasizes that different price regulation methods embody different degrees of incentive for efficiency improvements and play a crucial role in influencing profitability. In this context, Foster (2005) also addresses the importance of complementing the price stipulations with quality-of-service regulation, especially in cases where the private sector participates in water services production, because privately owned water companies may have an incentive to compromise on the quality of the service as a costcutting measure.

Therefore, being influenced by monopoly conditions and related economic regulations, the profits of water companies can vary significantly across different ownership structures and countries of operation (see Dore, Kushner \& Zumer, 2004; Hassanein \& Khalifa, 2007; Letza \& Smallman, 2001; Shaoul, 1997), which makes arriving at a consensus of what constitutes a legitimate profit rather challenging in this context (see Vinnari \& Näsi, 2008).

Private companies' involvement in water service delivery and the subsequent price increases have instigated opposition in various parts of the globe, some of the most famous cases being the popular protests in Cochabamba, Bolivia; Buenos Aires, Argentina; and Jakarta, Indonesia ${ }^{4}$ (e.g. Castro, 2007; Bakker, 2005; Loftus \& M CDonald, 2001). As a result of disappointing experiences with water services privatization/PPPs and active campaigning by social movements, numerous public authorities have decided to re-municipalize water supply and sewerage services, in other words return them to public ownership and control (Lobina, Kishimoto \& Petitjean, 2014). We concur with the views of these social movements and public authorities as we consider access to water services to be without a doubt a human right, and we are not in favour of extensive private sector participation in the delivery of these services ${ }^{5}$.

\subsection{Case context and data}

\footnotetext{
${ }^{4}$ In Ireland, government plans to corporatize water services and introduce domestic water billing were also contested by the public, resulting in legislation that, among other things, effectively prevents privatization (see Jollands and Quinn, 2017).

${ }^{5}$ We are not opposed to small-scale outsourcing of non-core operations such as facility maintenance.
} 
Our empirical study follows longitudinally the communications regarding profits in and around Tallinn Water (TW) Ltd. between 2008 and 2012. This company provides a unique research perspective for several reasons. First, TW has a mixed public-private ownership structure: the main shareholders are UK-based United Utilities ( 35.3 per cent) and the City of Tallinn ( 34.7 per cent), and 30 per cent of the shareholding is freely tradable. The shareholders' agreement provides that the largest private owner - United Utilities shall have operational control over TW, thus placing it in a dominant position in relation to the City's democratically elected representatives. By contrast, water services in 90 per cent of Estonian cities, or regional centres, are provided by fully publicly (municipally) owned and controlled water companies. Operating under lax national economic regulation that did not dictate 'justified' profitability calculations in the determination of water tariffs, TW was able to take advantage of its monopoly position and gradually increase the fees for water services, becoming one of the most profitable (see Appendix A) water companies in the EU (Dore et al., 2004; Hassanein \& Khalifa, 2007). Until 2010, the economic regulation of Estonian water and sewerage services was primarily left to local governments to arrange ${ }^{6}$ under stipulations within the national laws. The Public Water Supply and Sewerage Act 1999, the main regulatory instrument of water services provision in Estonia, was only a framework law, and as such it did not put forth any methodological approach to the calculation of costs when establishing water prices.

Notwithstanding these financial returns, water services for TW's customers remained very affordable during this period, with the average water bill comprising approximately only 1.2-1.3 per cent of household disposable income. The non-financial performance of TW also improved in terms of wastewater treatment, water quality (meeting EU quality criteria) and access to service (see Appendix B). During the 2001 partial privatization ${ }^{7}$, the City Government and the water company signed a 15-year service contract, which set out 97 detailed levels of service and the formula for determining water tariffs. According to the formula, the tariff for each year is based on the tariff of the previous year, adjusted in line with changes in the consumer price index (CPI) and a (K) coefficient agreed for each year. This price formula is similar to the one introduced by the economic regulator of the British water sector (The Office of Water Services; OFWAT) during the privatization of water and sewage utilities in England and Wales; however, the $\mathrm{K}$ coefficient in TW has never been negative to reflect productivity improvements, as would be the idea of such price-cap regulation (Kinnunen, 2005). Importantly, the service contract does not prescribe the amounts that TW should invest to comply with the 97 levels of service.

Though the increasing water tariffs and profits of TW caused dissatisfaction and criticism among some journalists and political parties of Tallinn also before 2009, they never led to thorough discussions on what a justified level of profitability should be nor did they cause any systematic attempts to tighten economic regulation over the water company. Therefore, even in the middle of a dramatic economic downturn in Estonia, resulting from the global financial crisis, TW announced that in accordance with the services agreement it would increase water tariffs by 12.8 per cent on 1 January 2009 . This raise, together with

\footnotetext{
${ }^{6}$ Local governments are entitled to appoint a water company and the latter must ensure the functioning and maintenance of the public water supply and sewerage system in its licensed territory.

${ }^{7}$ The 50.4 per cent privatization through an international tender was justified by the City Government primarily with the need for large capital investments in order to meet the quality standards required by national and European regulations. According to the City Council, the winner of the tender was chosen based on two criteria: the price offered for the shares and the stability of the tariff proposed for the next five years (Vinnari \& Hukka, 2007). This privatization was sponsored and closely guided by the European Bank for Reconstruction and Development (EBRD) that had been financing TW's investment projects since 1994.
} 
TW's stock announcement touting record-high profit figures for 2008, prompted different constituencies to loudly question the legitimacy of the company's profits. Consequently, in 2010 the parliament of Estonia adopted the Establishment of Price Restrictions on M onopolies Act (the Anti-M onopoly Law). The law aimed at forming the Estonian Competition Authority, a central independent regulator of water companies' prices and profits, and obliged Estonian water companies to present their price proposals for the approval of the Competition Authority from November 2010 onwards. Importantly, TW never reached an agreement on tariffs with the new economic regulator, which considered the water company's profit excessive. Our analysis focuses on the most intensive period of the public debate and ends in 2012, when emotions ran high and the parties stopped providing new arguments for profit (de)legitimation; the tariff dispute continued in court. In December 2017, the Supreme Court of Estonia made a final decision on TW's appeal stating that the Competition Authority is not bound by the agreements executed upon privatization and TW's tariffs will be regulated by the methodology developed by the Competition Authority. The water tariffs are still frozen at the 2010 level and TW remains involved in international arbitration proceedings in connection with the services contract.

Our empirical material consists of over 600 text documents, including national and international newspaper articles, online news, press releases, stock announcements, official letters, various performance reports, investor presentations, contracts, legislation, policy papers, and regulator's decisions. The method we employed in the analysis of this material is presented in the next section.

\subsection{Analytical method}

The CDA approach applied in this study is abductive in nature (Wodak, 2004); in our research we constantly moved 'back and forth between empirical findings and theoretical elements perceived to be of relevance and interest' (Lukka, 2014, p. 563). In other words, we developed our theoretical ideas regarding (de)legitimation alongside our empirical exploration of the case. To organize and analyse the case data, coding was conducted with the help of NVivo software when reading the collected documents and designating the meanings of sentences, both in relation to the theory and the other empirical materials. Hence, some of the codes were pre-defined (e.g. legitimation strategies) and some emerged during the data analysis (e.g. themes of struggle).

As is usual in CDA studies (Wodak, 2004; Vaara et al., 2006), it would be rather complicated for us to report all the rereading and reinterpretation stages of our analysis. However, retrospectively we can summarize that the analysis proceeded through four main stages, as follows: First, based on our empirical material, we created a timeline of the major events and mapped the counter-hegemonic who voiced their concerns regarding TW's profits. We identified the CEO of TW, investigative journalists and the Director General of the Competition Authority as the key actors and then examined the ways in which they made sense of the profitability of the privatized water services ${ }^{8}$. This sense-making analysis revealed the differences in the actors' profitability framings. Subsequently, we turned our focus to key themes in the different actors' communications by studying the collected texts in detail and coding them accordingly. As a result, we found

\footnotetext{
${ }^{8}$ Though a number of politicians from different political parties criticized each other and expressed their opinions on the tariffs and regulation of TW in the media (see also Appendix C), we deemed these expressions to be more about competing over votes than about the de-legitimation of TW's profit; therefore, politicians as a group of stakeholders remain relatively silent in our analysis.
} 
and then directed our attention towards several recurring and significant themes of struggle ('monopolist profit-making', 'dividend payout', 'tariff change/formula', 'privatization agreements and business plan') that prevailed in the communication between the actors. Figure 1 shows the distribution of textual data segments $(n=830)$, that is discursive units, containing arguments for or against TW's profits across the identified themes of struggle.

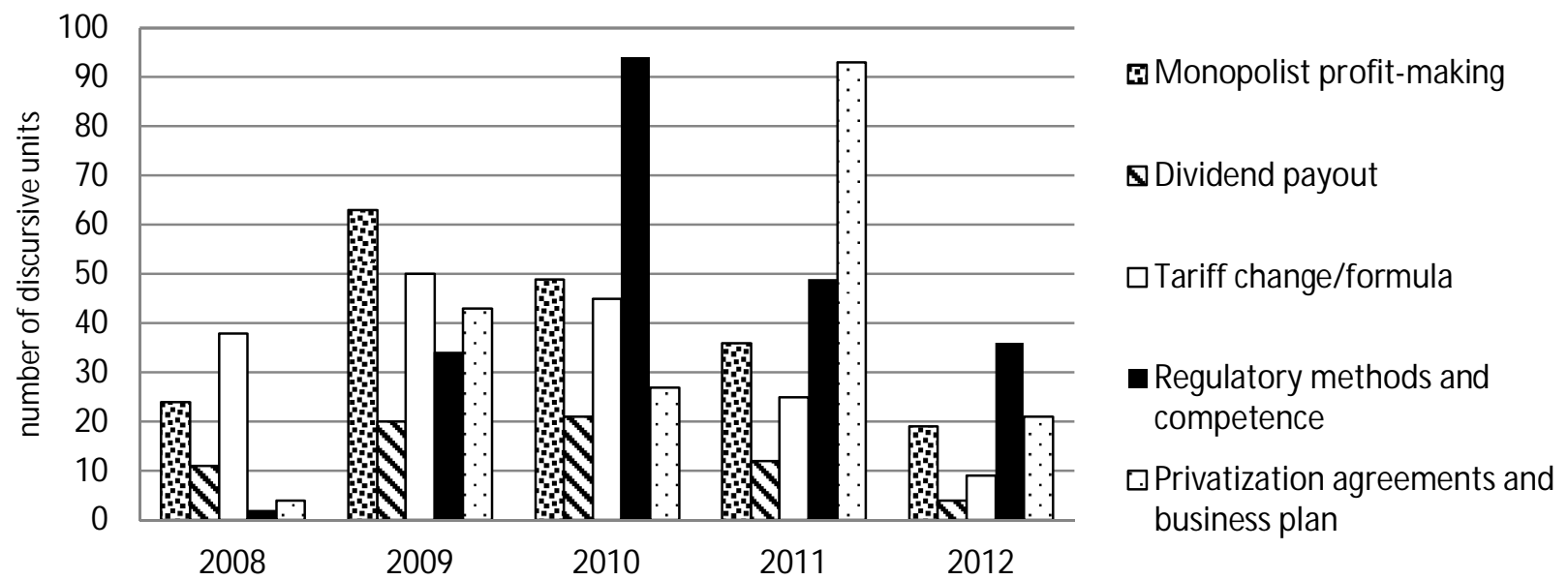

Fig. 1. Distribution of discursive units across the themes of struggle, 2008-2012

At this stage, we also filtered out the texts deemed irrelevant for further analysis (e.g. stock announcements with numeric performance information only).

Finally, following previous studies on legitimation struggles and strategies in organizational research (Vaara et al., 2006; Erkama \& Vaara, 2010; Vaara, 2014), we organized and coded the remaining texts according to the given discursive strategies of legitimation (i.e. normalization, authorization, rationalization, moral evaluation, narrativization/mythopoesis) used by the key actors. Figure 2 depicts the use of different discursive strategies between 2008 and 2012 alongside the major events of each year.

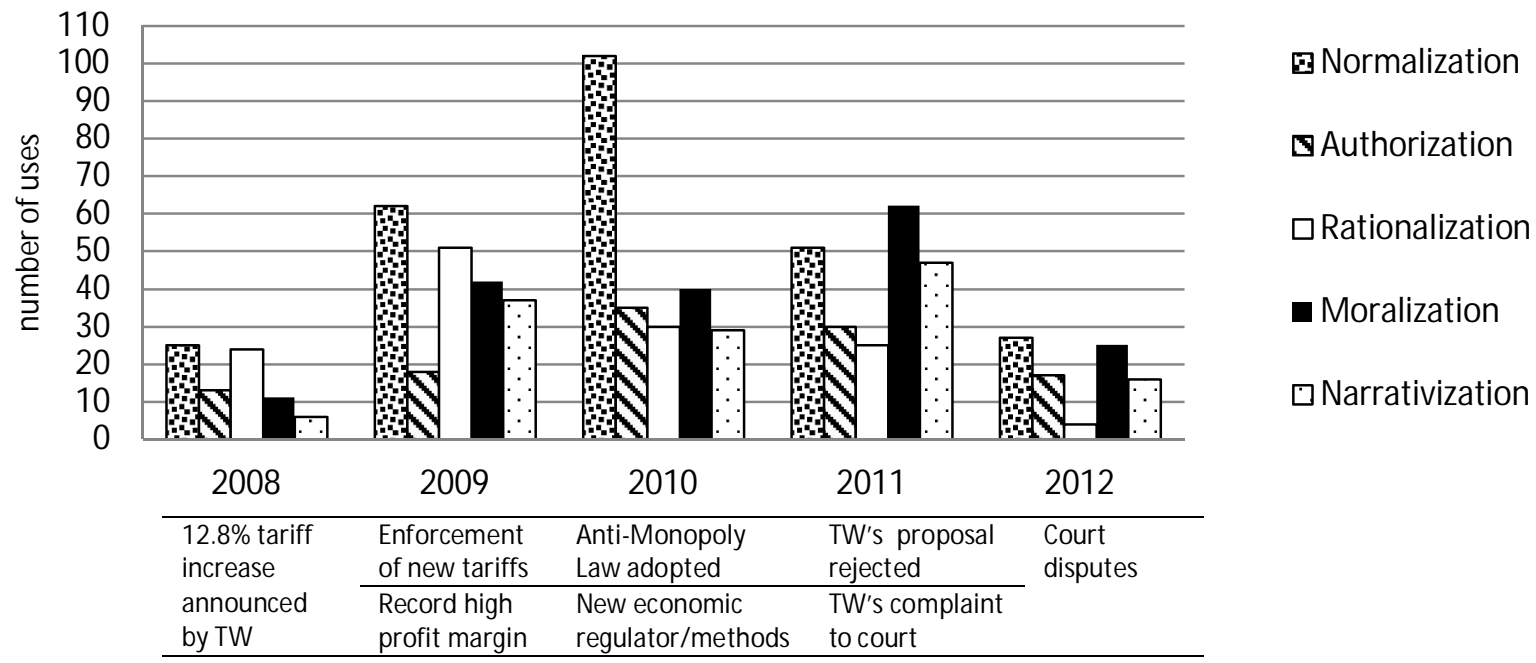




\begin{tabular}{lll}
\hline Economic \& & TW's proposal for & Regulator's \\
legal analyses & tariff increases & prescriptions \\
\hline
\end{tabular}

Fig. 2. Frequency of the use of discursive strategies and major events, 2008-2012

Figures 1 and 2 both indicate that the conflict concerning TW's profits became relatively antagonistic in 2009 and remained so until 2011, while the focal theme(s) and the frequency of mobilized legitimation strategies varied across the years. Since our interest was in fleshing out the major dynamics of legitimation-de-legitimation through decisive episodes in the conflict, we lastly analysed how the specific discursive strategies were mobilized in struggles associated with the identified themes. For this purpose, the texts also had to be organized chronologically across the key actors.

As regards intertextuality, the media coverage of different disputes and conflicts, such as claims of unjustified monopolist profit-making, usually included several references across various texts. Thus, the relevance of different comments and statements could often only be understood with reference to others considering the characteristics of the key actors and arenas. Therefore, the broader context, including the background and position of particular actors and media channels, was kept in mind when reading and analysing the relevance of the texts to our study.

\section{4. (De)legitimating the profit of Tallinn Water}

Table 1 illustrates the themes of the discursive struggles we identified from our empirical material and provides examples of the legitimation/de-legitimation strategies and dynamics that characterized the conflict concerning the profits of TW. That is, the table chronologically shows which discursive strategies (column 2), by whom and how (column 3) were used in debates around the themes of struggle (column 1) for profit (de)legitimation purposes, with selected illustrative quotes ${ }^{9}$. Table 1 focuses on some most decisive episodes of the conflict between 2009 and 2011, while Appendix C depicts the strategies used by each group over time. Based on this, we will next analyse the characteristics of these discursive struggles, (de)legitimation strategies, and dynamics.

\footnotetext{
${ }^{9}$ To keep Table 1 to a relatively manageable size, it was necessary to exclude from it some pieces of empirical material discussed in the text. These were mainly the comments of less prominent groups who only voiced their thoughts once or twice.
} 
Table 1 (De)legitimation strategies and dynamics in discursive struggles around the profitability of TW

\begin{tabular}{|c|c|c|c|c|}
\hline \multirow{2}{*}{$\begin{array}{l}\text { Theme } \\
\text { of } \\
\text { struggle }\end{array}$} & \multicolumn{2}{|c|}{ Strategy } & \multirow[b]{2}{*}{ Main arguments used for legitimation/ de-legitimation in the stakeholders' communications } & \multirow[b]{2}{*}{ Date } \\
\hline & Legit. & Delegit. & & \\
\hline \multirow{14}{*}{ 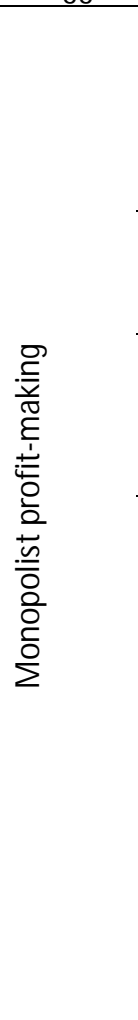 } & & Moral. & De-legitimation by referring to the immoral behaviour of historical business magnates: & \multirow{8}{*}{$\begin{array}{l}2 \mathrm{Apr} \\
2009\end{array}$} \\
\hline & & \multirow[t]{2}{*}{ Narrat. } & $\begin{array}{l}\text { 'The capital's water business is reminiscent of nineteenth-century America, where John D. Rockefeller and other business sharks easily made big gains. Later, they } \\
\text { were called predatory barons.' (Journalist Tänavsuu) }\end{array}$ & \\
\hline & & & De-legitimation by referring to abnormal profit margins: & \\
\hline & & Normal. & 'TW's operating profit margin was $56 \%$ last year! This is three times higher than that of similar water companies in Western Europe.' (Journalist Tänavsuu) & \\
\hline & Normal & & Legitimation by referring to exceeded obligations: & \\
\hline & & & $\begin{array}{l}\text { 'This [ } 56 \% \text { profit margin] is absolutely normal. ... when TW was privatized, the foundations of tariff setting and obligations were determined. We had to meet } \\
\text { certain quality standards, while all the risks and obligations had to be borne by investors. We have now met all the obligations and even exceeded them.' (CEO) }\end{array}$ & \\
\hline & Ration. & & Legitimation by referring to improved service quality and efficiency: & \\
\hline & & & $\begin{array}{l}\text { 'The company's willingness to provide more to Tallinners than stipulated in the Services Agreement or in legislation is witnessed in the quality facts, such as that } \\
\text { the water quality in Tallinn met } 98 \% \text { of all standards, while the EU standard is } 95 \% \text { and in } 2002 \text { the water quality level in Tallinn was } 63 \% \text {. The leakages level ... } \\
\text { has been reduced to below } 18 \% \ldots \text {, whereas the Services Agreement target required ... } 26 \% \text { against an initial position of } 35 \% \text {.' (CEO) }\end{array}$ & \\
\hline & & Normal. & De-legitimation by referring to abnormal profitability: & \\
\hline & & Author. & $\begin{array}{l}\text { 'Even the most optimistic analysts were surprised about the third-quarter results /.../ the company's net profit margin is an astonishing } 54.3 \% . / . . / \text { According to } \\
\text { analysts, this could make TW the most profitable utility in the world. For instance, ten water companies listed on the USstock exchange had a net profit margin } \\
\text { of between } 6.7 \text { and } 20.1 \% \text { last year.' (Business paper Äripäev/Baltic Business News) }\end{array}$ & $\begin{array}{l}23 \text { Oct } \\
2009\end{array}$ \\
\hline & & Moral. & De-legitimation by referring to managerial work and monopoly status: & \multirow{3}{*}{$\begin{array}{l}27 \text { Oct } \\
2009\end{array}$} \\
\hline & & & $\begin{array}{l}\text { 'It seems to us that only } 10 \% \text { of [TW's] extremely strong fundamentals depends on good work done by the company, while } 90 \% \text { depends on the monopoly status } \\
\text { and price agreements with the City government.' (Business paper Äripäev editorial) }\end{array}$ & \\
\hline & & Narrat. & $\begin{array}{l}\text { De-legitimation based on dramatic vocabulary and metaphors regarding monopoly status: } \\
\text { 'Competition Authority, please come help! Äripäev was depressed when reading the financial results of the monopoly TW - almost } 60 \% \text { profitability is a nice } \\
\text { achievement in entrepreneurship, but it seems to us and we feel indignant that the citizens of the capital [Tallinn] are being robbed.' (Business paper Äripäev } \\
\text { editorial) }\end{array}$ & \\
\hline & & $\begin{array}{l}\text { Normal. } \\
\text { Moral. }\end{array}$ & $\begin{array}{l}\text { De-legitimation based on reference to the free market as the opposite of monopoly status: } \\
\text { 'It's very difficult to justify that such a profit is reasonable, because in a free market there would never be such a profit.' (Estonian Chancellor of Justice) }\end{array}$ & $\begin{array}{l}25 \mathrm{Mar} \\
2010\end{array}$ \\
\hline \multirow{4}{*}{ 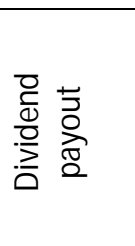 } & Ration. & & Legitimation by reference to water consumers' interests: & $20 \mathrm{Jan}$ \\
\hline & & & $\begin{array}{l}\text { 'One-third of the profit goes directly back to...the City of Tallinn. From the second third, all water consumers can benefit when buying the shares of TW.' (PR } \\
\text { manager) }\end{array}$ & 2009 \\
\hline & Ration. & & Legitimation by reference to shareholders' interests: & $27 \mathrm{Mar}$ \\
\hline & & & $\begin{array}{l}\text { 'We recognize our responsibilities [dividend payout of } 14.7 \text { million euros total] to all the owners, individual shareholders, pension funds, institutional investors } \\
\text { and the City of Tallinn, and their need to receive a return on their investment that is fair...' (CEO) }\end{array}$ & 2009 \\
\hline
\end{tabular}


Table 1 (Continued)

\begin{tabular}{|c|c|c|c|c|}
\hline \multirow{2}{*}{$\begin{array}{l}\text { Theme } \\
\text { of } \\
\text { struggle }\end{array}$} & \multicolumn{2}{|c|}{ Strategy } & \multirow[b]{2}{*}{ Main arguments used for legitimation/ de-legitimation in stakeholders' communications } & \multirow[b]{2}{*}{ Date } \\
\hline & Legit. & Delegit. & & \\
\hline \multirow{4}{*}{ 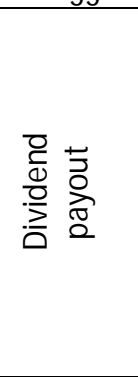 } & & Narrat. & $\begin{array}{l}\text { De-legitimation based on dramatic vocabulary and metaphors: } \\
\text { 'The citizens of the capital must feed a predatory capitalist profit machine that ... takes a large part of it [profit] abroad.' (Journalist Vedler) }\end{array}$ & \multirow{2}{*}{$\begin{array}{l}16 \mathrm{Apr} \\
2009\end{array}$} \\
\hline & & Ration. & $\begin{array}{l}\text { De-legitimation by reference to a uniquely abnormal dividend payout: } \\
\text { 'Sweet dividends are usually paid by "ready" companies that do not need money for further development. / .../ Over the last eight years the company has spent } \\
\text { on average as much as } 80 \% \text { of its pre-tax profit on dividends and related income tax.' (Journalist Vedler) }\end{array}$ & \\
\hline & & Moral. & $\begin{array}{l}\text { De-legitimation by reference to immoral behaviour: } \\
\text { '[TW] is milking the citizens of Tallinn like ravenous colonists once did with aborigines on banana islands.' (Journalist Vedler) }\end{array}$ & $\begin{array}{l}7 \text { May } \\
2009\end{array}$ \\
\hline & Ration. & & $\begin{array}{l}\text { Legitimation based on the need to attract financial investors: } \\
\text { 'Why invest in TW? A unique combination of stability and growth... A company committed to real growth in dividends year on year.' (CEO) }\end{array}$ & $\begin{array}{l}\text { July } \\
2009\end{array}$ \\
\hline \multirow{5}{*}{ 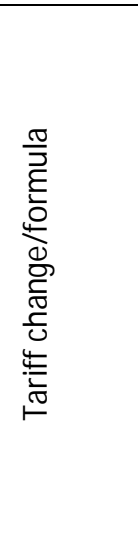 } & Ration. & & $\begin{array}{l}\text { Legitimation by reference to environmental protection and service quality: } \\
\text { 'To date, the company has achieved world standards regarding the quality of water, environmental impact, and customer services. Increasing costs ... set a great } \\
\text { challenge for us to maintain these service levels, which we are committed to further improving on behalf of the citizens and the wider environment.' (CEO) }\end{array}$ & $\begin{array}{l}10 c t \\
2008\end{array}$ \\
\hline & Narrat. & & $\begin{array}{l}\text { Legitimation by reference to the tariff formula: } \\
\text { 'A price increase depends on the consumer price index. This is not a percentage that TW simply dreamt up.' (PR manager) }\end{array}$ & $\begin{array}{l}20 J a n \\
2009\end{array}$ \\
\hline & & $\begin{array}{l}\text { Moral. } \\
\text { Author. }\end{array}$ & $\begin{array}{l}\text { De-legitimation by questioning the moral authority of the tariff formula: } \\
\text { 'Such a long-term contract where the water price would be increased on a yearly basis could be made perhaps only in Africa.' (DG of the Competition Authority) }\end{array}$ & \multirow{3}{*}{$\begin{array}{l}1 \mathrm{Dec} \\
2009\end{array}$} \\
\hline & & $\begin{array}{l}\text { Ration. } \\
\text { Normal. }\end{array}$ & $\begin{array}{l}\text { De-legitimation by reference to tariff-investment relationships: } \\
\text { 'It is not a normal business, where money is collected for } 10 \text { years in order to invest it during the eleventh year. That cannot be an argument. / ... I don't think we } \\
\text { should be witch-hunting, but I hope that in the end we could bring the water tariff down by } 25 \% \text {.' (DG of the Competition Authority) }\end{array}$ & \\
\hline & Author. & & $\begin{array}{l}\text { Legitimation by reference to approvals by the City government: } \\
\text { 'The company's opinion is that the tariffs have always been approved by the Tallinn City government in line with applicable legal acts, and to the best of the } \\
\text { company's knowledge there has been no decision by any relevant authority that would indicate otherwise.' (CEO) }\end{array}$ & \\
\hline \multirow{3}{*}{ 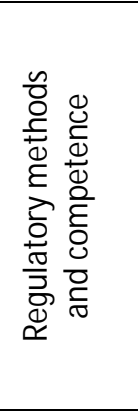 } & Normal. & & $\begin{array}{l}\text { Legitimation by reference to unused competence in the development of new economic regulations: } \\
\text { 'Without any hesitation, we consider ourselves a competence centre embodying the experience of United Utilities. M oreover, we consider it strange that } \\
\text { regarding this know-how, nobody has turned to TW.../../ We are ready for cooperation with all parties... in order to create a professional and balanced legal } \\
\text { economic regulation for the whole Estonian water sector...' (CEO) }\end{array}$ & $\begin{array}{l}15 \text { May } \\
2009\end{array}$ \\
\hline & & Normal. & $\begin{array}{l}\text { De-legitimation based on (the Competition Authority's) economic analyses of the Estonian water companies: } \\
\text { '[TW's] return on capital employed was } 16.9 \% \text { in } 2007 \text { and } 18.1 \% \text { in } 2008 \text {, while it should not exceed } 8.3 \% \text { for a water monopoly like TW.' (DG of the } \\
\text { Competition Authority) }\end{array}$ & $\begin{array}{l}30 \mathrm{Nov} \\
2009\end{array}$ \\
\hline & Normal. & & $\begin{array}{l}\text { Legitimation by reference to (the Competition Authority's) incompetently conducted economic analysis: } \\
\text { 'The analysis does not give full consideration to the company's past financial and service quality performance, future investment requirements, nor its potential } \\
\text { impact on the shareholders and banks that have been significant investors in TW since we listed....' (CEO) }\end{array}$ & $\begin{array}{l}1 \mathrm{Dec} \\
2009\end{array}$ \\
\hline
\end{tabular}


Table 1 (Continued)

\begin{tabular}{|c|c|c|c|c|}
\hline \multirow{2}{*}{$\begin{array}{l}\text { Theme } \\
\text { of } \\
\text { struggle }\end{array}$} & \multicolumn{2}{|c|}{ Strategy } & \multirow[b]{2}{*}{ Main arguments used for legitimation/ de-legitimation in stakeholders' communications } & \multirow[b]{2}{*}{ Date } \\
\hline & Legit. & Delegit. & & \\
\hline \multirow{7}{*}{ 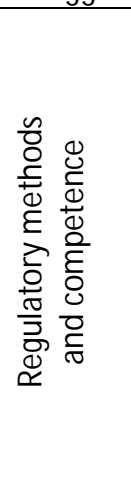 } & Author. & & Legitimation by reference to incompetently conducted profitability analysis: & \\
\hline & & & $\begin{array}{l}\text { 'The Competition Authority calculated that in } 2008 \text {, the weighted average cost of capital (WACC) for TW was } 8.31 \% \text {, when the average inflation rate that year } \\
\text { was } 10.4 \% \text {. This would lead to a negative return of }-1.9 \% \text {. This calculation is wrong and clearly not in accordance with the Competition Authority's own } \\
\text { objectives.. ... ...the Company's real return on invested capital since the privatization in } 2001 \text { has averaged less than } 8 \% \text {.' (CEO) }\end{array}$ & $\begin{array}{l}9 \text { Jun } \\
2010\end{array}$ \\
\hline & Author. & & Legitimation by reference to international regulatory practices: & \\
\hline & & & $\begin{array}{l}\text { 'We believe we are in accordance with international best practices for comparable enterprises around the world. Basing our calculations on the methodology } \\
\text { applied by the British water regulator Ofwat, often cited by the Competition Authority and the Legal Chancellor, the company's return on invested capital since } \\
\text { the privatization in } 2001 \text { has averaged } 9 \% \text {.' (CEO) }\end{array}$ & $\begin{array}{l}10 \text { Jun } \\
2010\end{array}$ \\
\hline & Author. & & Legitimation by reference to international regulatory practices, private ownership, and sustainability: & \\
\hline & Normal. & & '[TW's] multi-year [tariff] application accords with international norms for privatized water utility regulation and recognizes that the water industry has long & 10 Nov \\
\hline & $\begin{array}{l}\text { Ration. } \\
\text { Moral. }\end{array}$ & & $\begin{array}{l}\text { planning horizons. / ... We would expect the authorities to consider the real cost of capital and the actual value of invested capital when determining justified } \\
\text { profitability.' (CEO) }\end{array}$ & 2010 \\
\hline \multirow{12}{*}{ 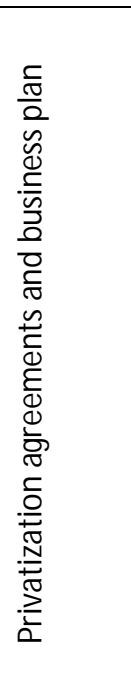 } & & Moral. & $\begin{array}{l}\text { De-legitimation by reference to the rule of law: } \\
\text { 'A contract cannot prevail over law.' (Head of Department of the Competition Authority) }\end{array}$ & $\begin{array}{l}7 \text { Aug } \\
2010\end{array}$ \\
\hline & Moral. & & Legitimation by reference to profit rights regarding the privatization: & \\
\hline & & & '...TW and its owners have met all the significant improvements in water services required under the privatization agreements, and to date have not yet made a & $5 / 6$ \\
\hline & & & return on the 85 million euro investment made in Estonia in 2001. All of this makes a unilateral breach of the contract half-way through the contract period & May \\
\hline & & & totally unacceptable... /../ Since 2001 the real rate of return on invested capital has been $6.5 \%$ and nobody can claim that this is unjustified profitability.' (CEO) & 2011 \\
\hline & Narrat. & & Legitimation by reference to damages stemming from a breach of the privatization contract: & $29 \mathrm{Jul}$ \\
\hline & & & $\begin{array}{l}\text { 'As a result of the unilateral breach of the fully legal privatization contract by the Estonian authorities, the company has been deprived of earning over } 600 \\
\text { thousand euros in } 2011 \text { that were contractually agreed in the business plan upon privatization.' (CEO) }\end{array}$ & 2011 \\
\hline & Ration. & & Legitimation by reference to benefits for water users resulting from the privatization: & \\
\hline & Author. & & $\begin{array}{l}\text { 'Had the Competition Authority done so [made an analysis of the performance improvements and increased efficiency since TW's privatization], it would have } \\
\text { understood that in all probability tariffs would have been hiaher and service standards much lower had the privatization never happened and had it been the }\end{array}$ & \\
\hline & & & $\begin{array}{l}\text { regulator since } 2001 \text {. The Competition Authority's instruction to reduce tariffs by } 29 \% \text { is based solely on its opinion that the privatization has not been beneficial } \\
\text { for the citizens of Tallinn, while it has provided no evidence to support this opinion.' (CEO) }\end{array}$ & 2011 \\
\hline & Moral. & & Legitimatization by reference to prevalence of the rule of law: & $180 \mathrm{ct}$ \\
\hline & & & $\begin{array}{l}\text { 'If now, ten years after the privatization, it is found that mistakes were made during the privatization, then it would be unfair to correct those by making those } \\
\text { investors who believed in TW at that time suffer...' (Attorney, privatization advisor) }\end{array}$ & 2011 \\
\hline
\end{tabular}

Note. Moral. =moralization, Narrat. =narrativization, Normal. =normalization, Ration. $=$ rationalization, Author. =authorization 


\subsection{Monopolist profit-making}

In general terms, different views on how much profit a company can earn often serve as the core of discursive struggles (Prakash, 2000). Accordingly, monopolist profit-making was the first theme that emerged in our analysis. The process of TW's sudden erosion of legitimacy in 2009, which begun from the company's decision to raise tariffs, was boosted by a w ell-known investigative journalist Toivo Tänavsuu. His article in a leading Estonian weekly paper followed soon after the announcement of TW's 2008 audited annual accounts - 11 per cent increase in turnover and 6.5 per cent increase in net profit - to the stock exchange at the end of M arch 2009. In his article, the journalist employed a combination of denormalization, moralization and narrativization to de-legitimate the water company's profit. He attempted to de-normalize the company's 56 per cent operating profit margin by emphasizing that it was three time higher than that of similar water companies in Western Europe. In turn, by comparing the Estonian capital's 'water business' to the activities of nineteenth-century 'business sharks', such as J ohn D. Rockefeller, the journalist engaged in outright moralization since such an expression leaves an unavoidable impression that there exists a serious moral problem in the behaviour of TW. In addition, the journalist offered a cautionary tale characteristic of narrativization as he pointed out that it was only in retrospect that such business magnates were labelled 'predatory barons'; thus implying that someone needs to act immediately in order to prevent the same thing from happening in present-day Tallinn.

By contrast, the CEO's reply ('this is absolutely normal') to the criticism in a complementary interview illustrates a typical normalization strategy. Unlike the journalist, he did not compare the profit margin with that of similar companies elsewhere in the world but considered the profit legitimate in the context of service obligations and business risks. M oreover, in a special stock announcement, TW highlighted its supernormal service quality ('willingness to provide more to Tallinners than stipulated...') and efficiency improvements ('leakage level in Tallinn has been reduced to below 18 per cent'). By highlighting these achievements, the CEO engaged in instrumental rationalization as he indicated that the company's prices and profits were a necessity for fulfilling a moral obligation, in this case meeting and even exceeding the requirements of quality-of-service regulation (Foster, 2005). Interestingly though, the company announcement contained no references to the actual profit figures heavily criticized in the journalist's article.

The article by Tänavsuu also instigated a flow of direct responses from political and other actors. The deputy mayor responsible for water services provision in Tallinn reacted to the article with a press release in which he strongly criticised the 2001 privatisation and admitted that the City Government could not unilaterally change existing contracts that have enabled the water company to dictate tariff changes. The M inister of Economic Affairs employed an indirect authorization strategy by declaring a day later that the situation would change once the Competition Authority had the legal mandate to approve water prices in Estonian municipalities. In the same article, the Director General of the Competition Authority utilized (de)normalization by stating that TW's return on capital should settle between 7-10 per cent, which he suggested was the normal level in "other countries". At that time, the Competition Authority was already working on an independent economic analysis, initiated soon after the announcement of TW's 2009 tariff increase, in order to analyse the compliance of TW's tariff setting with Estonian laws.

Soon after the critical article by Tänavsuu, his colleague Sulev Vedler, an award-winning investigative journalist, published another long, forceful piece on TW. Like his colleague, Vedler employed the de- 
normalization strategy by stating that TW's profitability in 2008 (a 41.1 per cent net profit margin) was four times higher than the reasonable level. He also engaged in outright moralization by calling the company a 'predatory capitalist profit machine' that borrowed from banks and unfairly charged water users with the result that the water prices in Tallinn were not affordable any more.

The media and other critical commentators became frustrated when TW surprised its investors by reporting a record high 54.3 per cent net profit margin for the third quarter of 2009. This result led some stock analysts and business journalists to call TW the most profitable water company in the world. Commenting on TW's announcement, Äripäev, the leading Estonian business paper, utilized denormalization by contrasting TW with water companies listed on the US stock exchange and pointing out that TW's profit was several times higher. The text of the newspaper's dramatic editorial 'Competition Authority, please come help!' also contained outright moralization as it stated that the citizens of Tallinn were being 'robbed' by the water company. Furthermore, Äripäev introduced a specific numeric estimate for assessing justified profitability, that is, the percentage of financial results depending on good management instead of monopoly position. By reporting that this figure was only 10 per cent in TW, the newspaper engaged in moral abstraction as it insinuated that the company's activities violated the societal norm that considers the misuse of monopoly position to be wrong.

In all, this discursive struggle shows how counter-hegemonic groups used emotional, morality-based arguments (Erkama \& Vaara, 2010) to point out that a public-private company's extremely high level of profitability was morally inappropriate and abnormal. Characteristic of such de-legitimation is that it is based on contrasting the company's profit with the 'normal' profit of a competitive firm or a public service provider and framing it as immoral and unjust due to emanating from the abuse of a dominant market position. TW's attempts to legitimate its profits and thus maintain the status quo took place through a combination of normalization and rationalization, which framed the profit as a regular business issue and a means to reach a societally desired end, namely improved service quality. The company did not wish to be seen as a monopoly but portrayed itself as a regular business organization that had in fact acted generously when it had exceeded the service levels stipulated in the privatization contract.

\subsection{Dividend payout}

A theme closely related to 'monopolist profit-making' was the dispute over dividend payouts; in other words, how the profits earned by TW should be used. When reporting on the audited financial results for 2008 , the CEO of TW noted that the company would pay 14.7 million euros in dividends in recognition of the shareholders' need to receive a fair return on their investment. Here, as is characteristic of the theoretical rationalization strategy, shareholders' rights are represented as "the way things are" (van Leeuwen \& Wodak, 1999, p. 107). This is further strengthened by TW's curious reference to water consumers as potential dividend receivers; it is implied that if the citizens of Tallinn were to purchase TW's shares, they too would demand dividends because "that's the way people are" (ibid).

In his critical response to the rationalization arguments provided by TW, journalist Vedler combined elements of narrativization, moralization, and rationalization to de-legitimate TW's dividends. His concern was that the largest part of the profit had been paid as 'fat' dividends to the private British water giant. In a follow-up article, Vedler used a number of colourful expressions to portray TW as an immoral actor (see Table 1). M oreover, Vedler linked his texts to his colleague's prior article by applying the same dramatically toned vocabulary of narrativization (e.g. the term 'predatory'). He also engaged in moral abstraction by 
referring to profits taken 'abroad' and using the metaphor of 'ravenous colonists' to describe TW. These expressions evoke the value of nationalism/patriotism, leaving the reader with an impression that foreignbased TW and United Utilities were swindling the citizens of Tallinn in a setting that could be viewed as modern-day colonialism. Vedler's texts also contained features of de-normalization and de-rationalization, as they depicted TW's profits as something uniquely abnormal in Estonia and disproportionate to the promised non-financial benefits. In the wake of Vedler's critique in a leading Estonian weekly paper, the legitimacy of TW's profits was also questioned by some influential politicians and public-sector managers using the authorization strategy by referring to other countries. For instance, Urmas Reinsalu, a well-known MP from the ruling national conservative IRL party, posted in his personal blog that according to European practice a reasonable profit in the water sector is ten per cent. Moreover, he demanded that 'the bridle must be put on' fast, the equestrian term evoking an image of TW as a wild horse that needed to be tamed before any further damage was inflicted.

However, a few months later in a roadshow presentation, the management board of TW continued advertising the company to financial investors as a steady revenue source with sustainable dividend growth. In other words, TW continuously relied on the initial rationalization argument about meeting its shareholders' expectations.

To summarize, TW's legitimation efforts in the dividend struggle rested on the neoliberal discourse of managerial accountability, which highlights the unique power position and rights of shareholders in the public-private company and privileges their financial interests. Nevertheless, the discursive struggle also illustrates how the profitability of a public-private water company can be dramatically challenged and senses of illegitimacy created through narrativization, de-normalization and moralization when most of the profits earned from providing local residents with basic services are distributed to 'foreign' private investors. By pointing out how this situation represents an inadequate reconciliation of the social and economic value generated by the public-private partnership (Hodge, 2006; Hodge and Greve, 2010), the counter-hegemonic groups effectively overshadowed the company's rationalising arguments regarding shareholders' justified profit expectations (Shirley and M enard, 2002; Grossi and Reichard, 2008).

\subsection{Tariff changes/ formula}

The third theme of the discursive struggles over TW's profitability concerned when, and by how much, water tariffs should be changed. A major struggle broke out between the CEO of TW and the Director General of the Competition Authority, since the new Anti-M onopoly Law of 2010 had authorized the Competition Authority to approve water prices in Estonian municipalities. M oreover, the Competition Authority had prepared an independent economic analysis of TW's justified profitability and tariff setting already before the adoption of the new law.

The core argument TW utilized to justify the inevitability of tariff increases was its commitment to environmental protection and service quality as a public value (Brinkerhoff and Brinkerhoff, 2011). This represents a typical case of discursive rationalization where practices are explained with reference to moral objectives at a societal level. Furthermore, when the Competition Authority stated that the company's tariff setting was not in line with the respective laws of that time, the CEO aligned his legitimating argument with the authorization strategy by implicating the City of Tallinn, which had approved all the tariff changes, indicating that the Competition Authority should not blame TW. M oreover, he utilized a strategy that can be called 'reverse' de-normalization, by pointing out that TW differed from the other, fully publicly 
owned, water monopolies in Estonia and the latter could not therefore serve as its benchmarks. In the same vein, the PR manager of TW employed autopoietic narrativization (Erkama and Vaara, 2010) by referring to the consumer price index component of the tariff formula ('This is not a percentage that TW simply dreamt up') to explain the tariff increases. In this context, the Director General of the Competition Authority called for TW to revise its business model, thus contributing to the de-legitimation of TW's profit in two ways. First, the statement that such contracts where prices are constantly raised are only made 'in Africa' is an instance of de-authorization meant to question the moral authority of TW's tariff formula. It could also be interpreted as a moralizing reference to the way in which multinational water companies have raised water prices in developing nations after privatization. Second, by employing a combination of rationalization and de-normalization, the Director General made an effort to undermine TW's argument about the need to generate solid profits in the present in order to have funds for investments in the future, stating that such was 'not a normal business'.

To conclude, by framing tariff increases as necessary actions that "everybody" would take to achieve the morally desirable ends of environmental protection and service quality, TW attempted to portray their profitability as inevitable. Characteristic of such instrumental rationalization is that though strongly mobilizing environmental and social arguments, it essentially relies on the neoliberal discourse of modernization that focuses on progress and economic rationales. However, this kind of inevitability claim was not difficult for the Competition Authority to challenge with de-authorization, de-normalization and rationalization because its counter-arguments essentially relied on a societal discourse that pursued a balance between the public and private benefits (Letza and Smallman, 2001; Brinkerhoff and Brinkerhoff, 2011).

\subsection{Regulatory methods and competence}

As a fourth theme of struggle over TW's profitability, that prevailed in the public debates during 2010, it is possible to distinguish the issue of competencies available for conducting economic analyses and drafting new methodological guidelines for water companies in Estonia. Already in M ay 2009, when the CEO of TW responded to journalist Vedler's critique by employing the authorization strategy, he claimed that the company constituted the best centre of competence in the field of economic regulation in Estonia and wondered why nobody was willing to use TW's or United Utilities' knowledge about how justified profitability in water services should be calculated. The Competition Authority sent a copy of its economic analysis to the Estonian Chancellor of J ustice, an independent supervisor of constitutional principles who, based on their legal analysis in M arch 2010, found that water tariffs in Tallinn breached the country's constitution and TW had earned an 'unreasonable' profit. A couple of days later, TW sent out a stock announcement reporting a record high (audited) annual profit for 2009, which was about 15 per cent more than in 2008. In June 2010, the Chancellor of J ustice, dissatisfied with the passivity of the City of Tallinn in implementing his proposal to bring the tariff regulation into accordance with laws, decided to challenge the matter in the Estonian Supreme Court. TW reacted to this news with a stock announcement where, employing de-authorization, the CEO tried to show that the Competition Authority's calculation of TW's justified profitability was incorrect (e.g. 'This would lead to a negative return of -1.9 per cent') and could be considered a simulation only.

The central issue related to the Competition Authority's calculative methodology concerned the factoring of the privatization value of TW into the calculation of invested capital. In a critical stock announcement, 
the CEO called for the Competition Authority to expand the definition of the regulated asset base and consider the privatization value of TW 'in accordance with best practice regulation for privatized utilities, such as that favoured by Ofwat in the UK'. The CEO thus clearly used the authorization strategy by appealing to the institutionalized knowledge-based authority of the British regulator Ofwat. This legitimation strategy was combined with normalization as TW implied that their profit margins would appear absolutely normal if Estonia only followed the regulatory principles used in the UK.

Furthermore, when commenting on TW's first tariff application to the Competition Authority, in which the company asked for annual tariff increases of almost three per cent for a multi-year period, the CEO of TW again employed normalization and rationalization strategies. Namely, he referred to the legitimating authority of international regulatory principles, underlining that TW's unique public-private ownership structure must be taken into account when assessing the legitimacy of its profitability. In other words, by incorporating the word 'privatized' into its communication, TW attempted to convince the Competition Authority that its profit margins are actually something normal for privatized water companies. Moreover, TW included elements of instrumental rationalization in its legitimation strategy by explaining that the request for tariff increases was a means to enable the consideration of sustainability-related long-term 'horizons'.

To summarize, this discursive struggle illustrates how the powerful public-private company assumed a defensive position against the critical regulatory and judicial authorities that had publicly declared the company's profit to be unreasonable. In doing so, TW relied on a double strategy of both de-authorizing the Competition Authority and authorizing its UK-based owner by appealing the latter's regulatory competence and rich experience from the UK's privatized water industry. This strategy is underpinned by a powerful ideologically laden discourse (J outsenvirta and Vaara, 2015) driven by the pursuit of ensured profitability in an international context. Characteristic of such a legitimation approach is that it promotes the privateeconomic view of water services along with the universality of profit expectations in order to challenge the role of national economic regulators in establishing the rules of game in the water sector.

\subsection{Privatization agreements and business plan}

Finally, as a last resort to retain its hegemonic position in 2011, TW employed authorization and moralization by referring to the agreements made during the privatization in 2001 . What was different this time in TW's communication was the emergence of a judicial tone, for instance when it referred to a 'unilateral breach of contract' by the other parties. Now the CEO of TW clearly started to address the 2001 privatization contracts, service quality improvement, and investor expectations as arguments against the Competition Authority. In summer 2011, when TW had submitted a legal complaint regarding the Competition Authority's decision not to accept its multi-period tariff application, the CEO presented TW as a victim, showcasing a financial figure to indicate how much TW had suffered ('... deprived of earning over 600 thousand euros...') due to the frozen tariffs. In doing so, the CEO continued to appeal to TW's moral right to maintain a level of profitability, presenting United Utilities as a wronged party that had signed a long-term contract in good faith. Furthermore, TW's communications became more dramatic in tone as the company increasingly began to use narrativization in its press materials.

Both the Estonian and international media described this evolving court dispute as a 'water war' as it also initiated a broader exchange of views. A well-known Estonian portfolio manager from an asset management company attempted to de-authorize the Competition Authority by stating that the latter had 
harmed Estonia's legal credibility with its 'adventures'. A partner of a leading law office in Estonia, who had also advised the British owners of TW during the 2001 privatisation, argued in a leading daily paper Eesti Päevaleht that it would be unfair to correct any mistakes made during the privatisation by making suffer those (investors) who believed in TW at that time. In other words, these experts, who had vested interests in the dispute, defended TW with one and the same argument - the prevalence of the privatization contract - that can be seen as an instance of the authorization strategy. TW and its supporters tended to present the size of the profit margins as something irrelevant compared to the real issue at stake: the trustworthiness of the Republic of Estonia in the eyes of international investors. In other words, in line with the normalization and moralization strategies, their argument was that the realized profitability level should be considered justified because 'normal' countries honour their promises (i.e. contracts). TW's opponents also resorted to moralization and (de)normalization. Ärileht, one of the leading business papers in Estonia, contributed to this discussion through a very critical article, referring also to the articles published earlier in Eesti Ekspress, in order to remind readers how the owners of TW had been 'milking' the company through dividends, management fees and the reduction of share capital. The article concluded by asking, 'if TW is not seen as a profitable business for United Utilities, then what can be considered profitable at all?'

To conclude, TW's appeals to the old privatization contracts and business plans illustrate its relatively low adaptability to changing societal expectations (Deegan and Unerman, 2011) and its managerial accountability primarily to the private shareholders (Shaoul et al., 2012; Letza and Smallman, 2001). In other words, characteristic of this legitimacy struggle is that it largely relied on the discourse of (legal) continuity and in so doing spoke for the view that only the contractual parties - the privatizer and the private buyer - may adjust or dissolve contractual relations in PPPs. TW's supporters' exhortations to honour the privatization contract can be understood as a way of implying that it is more important to convince international investors that Estonia is not a country where government intervenes in business, than it is to respect the legislation in force. Further, TW's increasing use of moralization and narrativization to depict itself and United Utilities as the victims of injustice suggest that the company was becoming alarmed because the counter-hegemonic groups were not giving up but in fact gaining ground.

\section{Discussion and conclusions}

Prior accounting research on PPPs has paid scant attention to the hybrid tensions associated with such undertakings, especially during the post-implementation period. While problems concerning the lack of transparency and accountability of PPPs have to some extent been identified, struggles between private and public actors over what constitutes a legitimate profit have rarely been documented. Thus, the main purpose of this paper was to begin addressing this gap in prior research by examining how senses of (il)legitimate profits are constructed in the discursive conflicts between a powerful public-private company and counter-hegemonic civic society groups. In particular, we were interested to learn which topics emerge as particularly salient in such debates as well as which linguistic means were utilized, and how, to represent a certain level of profit as (il)legitimate. To this end, we conducted a critical discourse analysis of publicly available material related to the profits of Tallinn Water, a public-private water company located in Estonia.

Our first aim was to identify key themes in the public debate concerning the profit of a PPP. From our empirical material, we identified five accounting-related themes, emanating from the nature of PPPs as hybrids of business firms and public service enterprises: monopolist profit-making; dividend payout; tariff 
change/ formula; regulatory methods and competence; as well as privatization agreement and business plan. We believe that similar themes are at the core of other public debates concerning privatized services, especially those that are natural monopolies like water, energy and, at least to some extent, the railway industry. This is because the general lesson from our study is that the profit motive is not considered morally acceptable in situations where citizens are forced to buy necessity services from a single dominant provider.

With reference to prior accounting research on PPPs, we can say that the developments in Tallinn bear a close resemblance to other analyzed cases. As suggested by Shaoul $(1997,2005)$, Shaoul et al. (2012) and Smyth and Whitfield (2017), the partial privatization of water services in Tallinn resulted in excessive gains to the private sector company and the company's persistent privileging of managerial accountability to shareholders came at the expense of public/social accountability to the broader society. The private benefits from the PPP arrangement clearly outweighed the public ones (see Letza and Smallman, 2001; Toms et al., 2011), violating civic society groups' sense of justice. Even though the prices for water services remained relatively affordable and TW exceeded its non-financial performance targets, the company's greed for profits prompted journalists, regulators, some politicians, and citizens to challenge the status quo through active de-legitimation of the profits.

Our second aim was to identify the textual means utilized to (de)legitimate a PPP's profit. In Tallinn, the erosion of legitimacy was boosted by journalists who adeptly combined dramatic narrativization with denormalization, moralization and de-rationalization in their related investigative articles. A dramatic and moralizing tone was also dominant in some other key constituencies' communications, typically along with the de-normalization and de-rationalization strategies. All these strategies served to highlight significant moral problems in TW's behaviour, especially its desire to maintain its abnormally high level of profitability. Interestingly, TW responded to the strong criticism primarily with rationalization and normalization strategies devoid of emotion. Dramatic narrativization as a legitimation strategy emerged in TW's communication only after two years of systematic de-legitimating attacks. Obviously, by that time public sentiment had already turned against TW: the consensus was that the annual profit margins of this apparently greedy water monopoly should be lowered.

The counter-hegemonic groups' de-legitimation strategies can be considered successful to the extent that an economic regulator was established for the Estonian water sector, this regulator deemed TW's profit to be inappropriately high, the Chancellor of Justice agreed with this assessment, and the Supreme Court's verdict confirmed the authority of the regulator over TW. The efforts made by TW to create legitimacy for its profits turned out to be relatively ineffective as it was not able to prevent litigation. In this sense, the case of TW supports the suggestions made in prior critical accounting research (e.g. Catchpowle and Cooper, 1999; Catchpowle and Smyth, 2016) that struggles over language provide disenfranchised groups with opportunities to contest oppressive structures by challenging dominant actors' interpretations of accounting information and concepts (such as profit).

On a more abstract level, our material indicates that the debate around the water company revolved around three main questions, namely: What is a normal profit for a public-private water company? Who or what is the ultimate authority or expert in such matters? What constitutes morally appropriate behaviour? As concerns the first question, the water company attempted to represent itself as a normal firm with the right to raise prices and make a profit, regardless of its monopoly status. Echoing neoliberal ideas, this 
strategy evokes the idea of what could be called 'decontextualized' capital that should be allowed to flow freely across borders and obey its own universal rules irrespective of the socio-historical context. According to such a view, the fact that a company is in a monopoly position does not matter; that a company's only product is a basic necessity and a human right, is irrelevant. The counter-hegemonic groups did their best to contextualize TW by discursively situating it among publicly owned water companies and other companies from competitive markets, showing how in this context the tariff increases and profitability of TW are abnormally large and poorly justified.

With regard to the question of who is the ultimate authority in water companies' profit-related issues, TW as a partially foreign-owned company attempted to undermine the knowledge base and expertise of the local regulators and authorities, appealing instead to the regulatory competence its British owner and the British water sector regulator. In doing so, the company effectively put forth the rather preposterous idea that it should be involved in determining how much it will be allowed to charge from the water users in Tallinn in order to satisfy the demands of its investors. Such ideas of self-regulation again hark back to the naïve neoliberal belief that companies can be trusted to act ethically on a voluntary basis, and to the partially associated agenda to reduce government 'interference' in business operations. TW's critics in turn trusted the local regulator and were also otherwise suspicious of the condescending, almost colonialist attitude of the company. The verdict of the Estonian Supreme Court clearly indicated that the company should respect and abide by the local rules instead of "international best practices"; albeit this had little effect on the company, which is still involved in international arbitration regarding this issue.

Finally, concerning the third question of morality, throughout the conflict TW tried to assume the role of a benefactor entitled to such a large profit because of its generosity - it had, after all, largely exceeded the stipulated performance targets. Towards the end of the struggle, when the company realized that the public opinion had turned against it, it tried to turn the tables around by portraying itself and the shareholders as the wronged parties, victims of injustice deprived of profits that were promised to them in the privatization contracts. This privileging of a business contract over national acts of legislation yet again evokes neoliberal values whereby business interests trump public interest and wellbeing. TW's opponents, in contrast, declared the company an immoral actor trying to abuse its commanding market position to make excessive gains and transfer part of the profits outside national borders in the form of dividends.

From a discursive perspective, the struggles analysed in this study are micro-level manifestations of the clash of two macro level discourses (Alvesson and Kärreman, 2011), international-capitalist and societal (Joutsenvirta and Vaara, 2015), each of which holds a different perception of the nature of water services (Schouten and Schwartz, 2006). The international-capitalist discourse promotes shareholder value, managerial accountability, progress and service improvement. It is underpinned by a neoliberal world view that believes in the commoditization of natural resources and the ability of markets to produce a societally just outcome with little government intervention. The international-capitalist discourse therefore portrays water as a private-economic good and considers profit-making on water services to be legitimate as long as essential non-financial performance standards are met. Ultimately, such discourse aims at de-politicization, the removal of essentially political decisions from the public sphere by presenting them as non-political (e.g. Teivainen, 2002). The societal discourse in turn provides a broader view of relevant constituencies, including marginalized and oppressed ones, emphasizing the importance of equality and the balance between financial and non-financial performance in the provision of public services. This discourse is based on a view of water as a merit good, a public good and a human right (UN, 2010), also highlighting that 
water services exhibit the characteristics of a natural monopoly (Parker, 1999). The societal discourse therefore correctly recognizes that water services provision cannot be left to market forces without public intervention, and represents profit-making as illegitimate.

To summarize, we believe our study to make three contributions to prior accounting research. First, with the findings elaborated above, we complement extant knowledge on the effects of PPPs in operation (e.g. Shaoul, 1997; Acerete et al., 2011; Toms et al., 2011) by focusing on legitimacy struggles related to a key accounting construct, namely the profit of a public-private organization. Second, we illustrate the applicability of the discursive strategies of legitimation framew ork (van Leeuwen, 1996; Vaara et al., 2006) to accounting researchers interested in exploring legitimation struggles. We consider the framework useful as it does not consider stakeholders merely as passive audiences that are relatively easy to manipulate by organizations, as is often assumed in accounting research (e.g. Andon et al., 2014; O'Dwyer et al., 2011) informed by the work of prominent legitimacy scholars such as Suchman (1995). Rather, different audiences can take the initiative in implementing de-legitimation strategies or combinations thereof (Erkama and Vaara, 2010). Our third contribution consists in responding to the calls of Andon (2012) as well as Hodge and Greve (2018) by offering a theoretically informed PPP analysis situated in a thus far neglected geographical context, namely Estonia. The case of TW presents a situation in which a powerful multinational water company tried to transfer its own rules of the game from one country (the UK) to another (Estonia), where such attempts were perceived as inappropriate, perhaps even as manifestations of modern-day colonialism.

As concerns the limitations of the study, we have focused on the textual strategies employed in the (de)legitimation struggles surrounding the profit of a public-private water company. Although it is difficult to establish the concrete effects of discourses, we remain relatively confident that the de-legitimation strategies employed by the critics of TW accelerated the process whereby water companies became legally subject to economic regulation by the Competition Authority and whereby the Chancellor of Justice decided to take the case to court. However, we have not taken into consideration the institutional and cultural factors that are also likely to have influenced these developments. We therefore propose that future research could take a deeper look at the local cultural and institutional contingencies alongside (de)legitimation arguments.

In addition, although we have acknowledged that different constituencies utilized combinations of strategies in the struggles, we have not attempted to probe the significance of such combinations. In this sense, our case study, which in many ways is only a beginning, proposes that future research could analyse the design and use of interrelated legitimation strategies/techniques as a 'package'. Gaining a broader understanding of the legitimation package, we believe, could facilitate the development of theory on how legitimacy changes and whether different legitimation strategies effectively complement or substitute each other. The insights thus developed could also provide useful tools for counter-hegemonic groups seeking to change oppressive social structures (see below).

In terms of practical implications for social movements contesting privatization or PPP arrangements, our analysis indicates that dramatic narrativization appears to be a fairly effective approach for de-legitimizing profit-making in public-private service delivery while the normalization and authorization strategies alone usually addressing technicalities such as tariff formulas and quality indicators - do not suffice to morally engage audiences. Emotional arguments, as a typical element of narrativization and moralization, become 
significant for creating senses of illegitimacy since they are a way of engaging an audience and inciting them to speak out in public against an injustice (see e.g. Boltanski, 1999).

Another implication of the study concerns political decision makers contemplating extensive private sector involvement in water services delivery. As water is essential to all forms of life, including human beings, it is not justified for PPPs - even when quality, access and affordability are ensured - to impose prices that exceed the costs of operation, maintenance and capital charges. The recent re-municipalization trend is testament to the necessity of retaining water services in public ownership and control.

\section{Acknowledgements}

We gratefully acknowledge the helpful comments given by Albrecht Becker, Sven M odell, Janne Tienari, Jarmo Vakkuri, and the participants at research seminars held at the University of Turku and the University of Tampere.

\section{References}

Acerete B, Stafford A, Stapleton P. Spanish healthcare public private partnerships: The 'Alzira model'. Critical Perspectives on Accounting 2011;22(6):533- 549.

Agyenim-Boateng C, Stafford A, Stapleton P. The role of structure in manipulating PPP accountability. Accounting, Auditing \& Accountability Journal 2017;30(1):119-144.

Alvesson M, Kärreman D. Decolonializing discourse: Critical reflections on organizational discourse analysis. Human Relations 2011; 64(9):1121-1146.

Alvesson M , Kärreman D. Taking the linguistic turn in organizational research: Challenges, responses, consequences. Journal of Applied Behavioural Science 2000; 36(2):134-156.

Andon P. Accounting-related research in PPPs/PFls: present contributions and future opportunities. Accounting, Auditing \& Accountability Journal 2012;25(5):876-924.

Andon P, Free C, Sivabalan P. The legitimacy of new assurance providers: Making the cap fit. Accounting, Organizations and Society 2014;39(2):75-96.

Archer MS. Realist Social Theory: The M orphogenetic Approach. 1995; Cambridge, M A: Cambridge University Press.

Asenova D, Beck M. Crucial silences: When accountability met PFI and finance capital. Critical Perspectives on Accounting 2010;21:1-13.

Bakhtin M M. The Dialogic Imagination: Four Essays. Ed. M ichael Holquist. Trans. Caryl Emerson and Michael Holquist. 1981; Austin and London: University of Texas Press.

Bakker K. Trickle down? Private sector participation and the pro-poor water supply debate in Jakarta, Indonesia. Geoforum 2005;38(5):855-868. 
Bebbington J, Brown J, Frame B, Thomson I. Theorizing engagement: the potential of a critical dialogic approach. Accounting, Auditing \& Accountability Journal 2007;20(3):356-381.

Benito B, M ontesinos V, Bastida F. An example of creative accounting in public sector: The private financing of infrastructures in Spain. Critical Perspectives on Accounting 2008;19:963-986.

Bhaskar RA. Realist Theory of Science. 1975; Leeds: Leeds Books.

Boltanski L. Distant Suffering: M orality, Media and Politics. 1999; Cambridge (UK): Cambridge University Press.

Bouckaert G, Halligan J. M anaging performance: International comparisons. 2008; New York: Routledge.

Bourdieu P, Wacquant L. NeoLiberalSpeak: Notes on the new planetary vulgate. Radical Philosophy 2001; 105(Jan):1-6.

Brinkerhoff D, Brinkerhoff J. Public-private partnerships: perspectives on purposes, publicness, and good governance. Public Administration and Development, 2011;31:2-14.

Broadbent J, Gill J, Laughlin R. Identifying and controlling risk: The problem of uncertainty in the private finance initiative in the UK's National Health Service. Critical Perspectives on Accounting 2008;19:40-78.

Broadbent J, Gill J, Laughlin R. The Private Finance Initiative in the National Health Service: Nature, emergence and the role of management accounting in decision making and post-decision project evaluation. Research Full Report. 2004; London: The Chartered Institute of Management Accountants (CIMA).

Broadbent J, Laughlin R. Control and legitimation in government accountability processes: the Private Finance Initiative in the UK. Critical Perspectives on Accounting 2003a;14: 23-48.

Broadbent J, Laughlin R. Public Private Partnerships: an introduction. Accounting, Auditing \& Accountability Journal 2003b;16(3):332-41.

Broadbent J, Laughlin R. The role of PFI in the UK Government's modernization agenda. Financial Accountability and M anagement 2005;21(1):75-97.

Brown J. Democratizing accounting: reflections on the politics of 'old' and 'new' pluralisms. Critical Perspectives on Accounting 2017;43:20-46.

Brown J. Democracy, sustainability and dialogic accounting technologies: Taking pluralism seriously. Critical Perspectives on Accounting 2009;20(3):313-342.

Burke R, Demirag I. Changing perceptions on PPP games: Demand risk in I rish roads. Critical Perspectives on Accounting 2015;27:189-208.

Castro JE. Poverty and citizenship: Sociological perspectives on water services and public-private participation. Geoforum 2007;38(5):756-771.

Catchpowle L, Cooper C. No escaping the financial: The economic referent in South Africa. Critical Perspectives of Accounting 1999;10:711-746. 
Catchpowle L, Smyth S. Accounting and social movements: an exploration of praxis and the class nature of accounting information. Accounting Forum 2016;40(3): 220-234.

Cho $\mathrm{CH}$. Legitimation strategies used in response to environmental disaster: A French case study of total SA's Erika and AZF Incidents. European Accounting Review 2009;18(1):33-62.

Clegg S. The State, power, and agency: missing in action in institutional theory. Journal of M anagement Inquiry 2010;19(1):4-13.

da Cruz NF, M arques RC. M ixed companies and local governance: no man can serve two masters. Public Administration 2012;(90)3: 737-758.

Deegan C, Unerman J. Financial Accounting Theory. 2011; Berkshire: M cGraw-Hill Higher Education.

Demirag I, Khadaroo I, Stapleton P, Stevenson C. The diffusion of risks in public private partnership contracts. Accounting, Auditing \& Accountability Journal 2012;25(8):1317-1339.

Dillard J, Brown J. Broadening out and opening up: An agonistic attitude toward progressive social accounting. Sustainability Accounting, M anagement and Policy Journal 2015;9(2):243-66.

Dillard JF, Rigsby JT, Goodman C. M aking and remaking the organizational context. Duality and the institutionalization process. Auditing, Accounting and Accountability Journal 2004;17(4):506-42.

Dore M, Kushner J, Zumer K. Privatization of water in the UK and France - What can we learn? Utilities Policy 2004;12:41-50.

Dowling J, Pfeffer J. Organizational legitimacy: social values and organizational behaviour. Pacific Sociological Review 1975;18:122-136.

English L, Guthrie J. Driving privately financed projects in Australia: what makes them tick? Accounting, Auditing \& Accountability Journal 2003;16(3): 493-511.

Erkama N, Vaara E. Struggles over legitimacy in global organizational restructuring: a rhetorical perspective on legitimation strategies and dynamics in a shutdown case. Organization Studies 2010;31:813-839.

Fairclough N. Discourse and Social Change. 1992; Cambridge: Polity Press.

Fairclough N. Analysing Discourse: Textual Analysis for Social Research. 2003; London, UK: Longman.

Fairclough N. Critical Discourse Analysis. The Critical Study of Language. 2010;Harlow: Longman.

Finger M , Finon D. From 'service public' to universal service: the case of the European Union, in M. Finger and R. W. Künneke (eds.) International Handbook of Network Industries. The Liberalization of Infrastructures. 2001. Cheltenham: Edward Elgar.

Foster V. Ten years of water service reform in Latin America: toward an Anglo-French model. Water Supply and Sanitation Sector Board Discussion Paper Series, Paper No. 3: January 2005. Washington, DC: The World Bank.

Freire P. Pedagogy of the Oppressed. 1970; New York, NY: Seabury. 
Freire P. The Politics of Education: Culture, Power and Liberation. 1985; London: M acmillan.

Grant D, Keenoy T, Oswick C (Eds.) Discourse and Organization. 1998; London: Sage.

Grossi G, Reichard C. M unicipal corporatization in Germany and Italy. Public Management Review 2008;10:597-617.

Hassanein A, Khalifa R. Financial and operational performance indicators applied to public and private water and wastewater utilities. Engineering, Construction and Architectural Management 2007;14:479492.

Heald D, Georgiou G. The substance of accounting for public-private partnerships. Financial Accountability \& M anagement 2011; 27(2):217-247.

Hodge G. Public Private Partnerships and Legitimacy. UNSW Law Journal 2006;29:318-327.

Hodge G, Greve C. Public-private partnerships: governance scheme or language game? Australian Journal of Public Administration 2010;69:8-22.

Hodge G, Greve C. Contemporary public-private partnership: Towards a global research agenda. Financial Accountability \& Management 2018;34:3-16.

ICWE (1992). The Dublin Statement and Report of the Conference. International Conference on Water and the Environment: Development Issues for the 21st century. 26-31 January. Dublin.

Jollands S, Quinn M. Politicising the sustaining of water supply in Ireland - the role of accounting concepts. Accounting, Auditing \& Accountability Journal 2017;30(1):164-190.

Jørgensen M, Phillips L. Discourse Analysis as Theory and M ethod. 2002; London: Sage.

Joutsenvirta $M$, Vaara E. Legitimacy struggles and political corporate social responsibility in international settings: a comparative discursive analysis of a contested investment in Latin America. Organization Studies 2015;36(6):741-777.

Khadaroo I. The actual evaluation of school PFI bids for value for money in the UK public sector. Critical Perspectives on Accounting 2008;19(8):1321-1345.

Kinnunen K. Pricing of electricity distribution: an empirical efficiency study in Finland, Norway and Sweden. Utilities Policy 2005;13(1):15-25.

Laclau E, M ouffe C. Hegemony and Socialist Strategy: Towards a Radical Democratic Politics. 1985; London, New York: Verso.

Laine M, Vinnari $E$. The transformative potential of counter accounts: a case of animal rights activism. Accounting, Auditing \& Accountability Journal 2017;30(7):1481-1510.

Letza S, Smallman C. Est in aqua dulci non invidiosa voluptas. In pure water there is a pleasure begrudged by none: on ownership, accountability and control in a privatized utility. Critical Perspectives on Accounting 2001;12(1):65-85. 
Lieberherr E, Fuenfschilling L. Neoliberalism and sustainable urban water sectors: A critical reflection of sector characteristics and empirical evidence. Environment and Planning C: Politics and Space 2016;34(8): 1540-1555.

Lobina E, Kishimoto S, Petitjean O. Here to stay: water remunicipalisation as a global trend. 2014. Public Services International Research Unit (PSIRU), Transnational Institute (TNI) and M ultinational Observatory. https:// www.tni.org/files/download/heretostay-en.pdf. Accessed 19 M arch, 2019.

Loftus A, M cDonald DA. Of liquid dreams: a political ecology of water privatization in Buenos Aires. Environment and Urbanization 2001;13(2):179-199.

Lukka K. Exploring the possibilities for causal explanation in interpretive research. Accounting, Organizations and Society 2014;39(7):559-566.

M erkl-Davies DM , Koller V. 'M etaphoring' people out of this world: A Critical Discourse Analysis of a chairman's statement of a UK defence firm. Accounting Forum 2012;36(3):178- 193.

M iller P, Kurunmaki L, O'Leary T. Accounting, hybrids and the management of risk. Accounting, Organizations and Society 2008;33(7-8):942-67.

M odell S. M aking institutional accounting research critical: dead end or new beginning? Accounting, Auditing \& Accountability Journal 2015;28(5):773-808.

M oll J, Hoque Z. Budgeting for legitimacy: The case of an Australian university. Accounting, Organizations and Society 2011;36(2):86-101.

M ouffe C. Agonistics: Thinking the World Politically. 2013; London: Verso.

M usgrave RA. The theory of public finance. 1959; New York and London: M cGraw-Hill.

Newberry S, Pallot J. Fiscal (ir)responsibility: privileging PPPs in New Zealand. Accounting, Auditing \& Accountability Journal 2003;16(3):467-92.

O'Donovan G. Environmental disclosures in the annual report: Extending the applicability and predictive power of legitimacy theory. Accounting, Auditing \& Accountability Journal 2002;15(3):406-436.

O'Dwyer B, Owen D, Unerman J. Seeking legitimacy for new assurance forms: The case of assurance on sustainability reporting. Accounting, Organizations and Society 2011;36(1):31-52.

Parker D. Regulation of privatised public utilities in the UK: performance and governance. International Journal of Public Sector Management 1999;12(3):213-235.

Phillips N, Oswick C. Organizational Discourse: Domains, Debates, and Directions. Academy of Management Annals 2012;6(1):35-481.

Philips N, Lawrence TB, Hardy C. Discourse and Institutions. The Academy of M anagement Review 2004;29(4):635-652.

Prakash A. Greening the Firm: The Politics of Corporate Environmentalism. 2000; Cambridge: Cambridge University Press. 
Putnam L, Cooren F. Alternative perspectives on the role of text and agency in constituting organizations. Organization 2004;11(3):323-333.

Rogers P, de Silva R, Bhatia R. Water is an economic good: How to use prices to promote equity, efficiency and sustainability. Water Policy 2002;4(1):1-17.

Rojo LM , van Dijk T. 'There was a problem, and it was solved!' Legitimating the expulsion of 'illegal' migrants in Spanish parliamentary discourse. Discourse and Society 1997;8(4):523-566.

Samuelson PA. The pure theory of public expenditure. The Review of Economics and Statistics 1954;36(4):387-389.

Schouten M, Schwartz K. Water as a political good: implications for investments. International Environmental Agreements: Politics, Law and Economics 2006;6(4):407-421.

Shaoul J. A critical financial analysis of the Private Finance Initiative: selecting a financing method or allocating economic wealth? Critical Perspectives on Accounting 2005;16(4): 441-471.

Shaoul J. A critical financial analysis of the performance of privatised industries: the case of the water industry in England and Wales. Critical Perspectives on Accounting 1997;8(5):479-505.

Shaoul J, Stafford A, Stapleton P. The cost of using private finance to build, finance and operate hospitals. Public Money and M anagement 2008;28(2):101-108.

Shaoul J, Stafford A, Stapleton P. Financial black holes: The disclosure and transparency of privately financed roads in the UK. Accounting, Auditing \& Accountability Journal 2010;23(2):229-255.

Shaoul J, Stafford A, Stapleton P. Accountability and corporate governance of public private partnerships. Critical Perspectives on Accounting 2012;23(3):213-229.

Shirley M , M enard C. Cities Awash: A Synthesis of the Country Cases, in M. Shirley (ed) Thirsting for Efficiency: The Economics and Politics of Urban Water System Reform. 2002; New York: Pergamon/Elsevier.

Smyth S, Whitfield D. M aintaining market principles: Government auditors, PPP equity sales and hegemony. Accounting Forum 2017;41(1):44-56.

Spence C, Husillos J, Correa-Ruiz C. Cargo cult science and the death of politics: A critical review of social and environmental accounting research. Critical Perspectives on Accounting 2010;21(1):76-89.

Suchman M C. M anaging legitimacy: strategic and institutional approaches. Academy of M anagement Review 1995;20(3):571-610.

Suddaby R, Greenwood R. Rhetorical strategies of legitimacy. Administrative Science Quarterly 2005;50(1):35-67.

Teivainen T. Enter Economism, Exit Politics: Experts, Economic Policy and the Damage to Democracy. 2002; London and New York: Zed Books.

Toms S, Beck M , Asenova D. Accounting, regulation and profitability: The case of PFI hospital refinancing. Critical Perspectives on Accounting 2011;22(7):668- 681. 
Tregidga H, M ilne M, Kearins K. (Re)presenting 'sustainable organizations'. Accounting, Organizations and Society 2014;39(6):477-494.

Tregidga H, M ilne M, Lehman G. Analyzing the quality, meaning and accountability of organizational reporting and communication: Directions for future research. Accounting Forum 2012;36(3):223-230.

UN (2010). UN General Assembly Resolution 64/292, 2010.

UN Committee on Economic, Social and Cultural Rights (2002). General Comment No. 15 UN Doc. $\mathrm{E} / \mathrm{C} \cdot 12 / 2002 / 11$.

Vaara E. Struggles over legitimacy in the Eurozone crisis: Discursive legitimation strategies and their ideological underpinnings. Discourse \& Society 2014;25(4):500-518.

Vaara E, Tienari J. A discursive perspective on legitimation strategies in multinational corporations. Academy of M anagement Review 2008;33(4):985-993.

Vaara E, Tienari J, Laurila J. Pulp and paper fiction: On the discursive legitimation of global industrial restructuring. Organization Studies 2006;27(6):789-810.

van Leeuwen T. The Grammar of Legitimation. Unpublished manuscript. 1996; School of M edia, London College of Printing.

van Leeuwen T, Wodak R. Legitimizing immigration control: a discourse-historical analysis. Discourse Studies 1999;1(1):83-118.

Vinnari E, Hukka J. Great expectations, tiny benefits - Decision-making in the privatization of Tallinn water. Utilities Policy 2007;15(2):78-85.

Vinnari E, Näsi S. Creative accrual accounting in the public sector: 'Milking' water utilities to balance municipal budgets and accounts. Financial Accountability \& Management 2008;24(2):97-116.

Volosinov VN. Marxism and the philosophy of language (translated by M atejka L, Titunik IR). 1973; New York and London: Seminar Press.

Weihe G. Ordering disorder - on the perplexities of the partnership literature. The Australian J ournal of Public Administration 2008;67(4):430-442.

Wodak R. Critical discourse analysis. In C. Seale, G. Gobo \& J.F. Gubrium (eds.) Qualitative Research Practice. 2004; Thousand Oaks, CA: Sage.

Wodak R, M eyer M. Critical Discourse Analysis: History, Agenda, Theory, and Methodology. In R. Wodak, \& M. Meyer (Eds.). Methods for Critical Discourse Analysis. 2009; London: Sage Publications.

Wodak R, De Cillia R, Reisigl M , Liebhart K. The discursive construction of national identity. 1999; Edinburgh, UK: Edinburgh University Press.

Woodward DG, Edwards P, Birkin E. Organizational legitimacy and stakeholder information provision. British Journal of Management 1996;7(4):329-347. 
Zald M N, Lounsbury, M. The wizards of Oz: towards an institutional approach to elites, expertise and command posts. Organization Studies 2010;31(7):963-996.

\section{Appendix A. The dynamics of TW's financial performance and investments, 2000-2014}

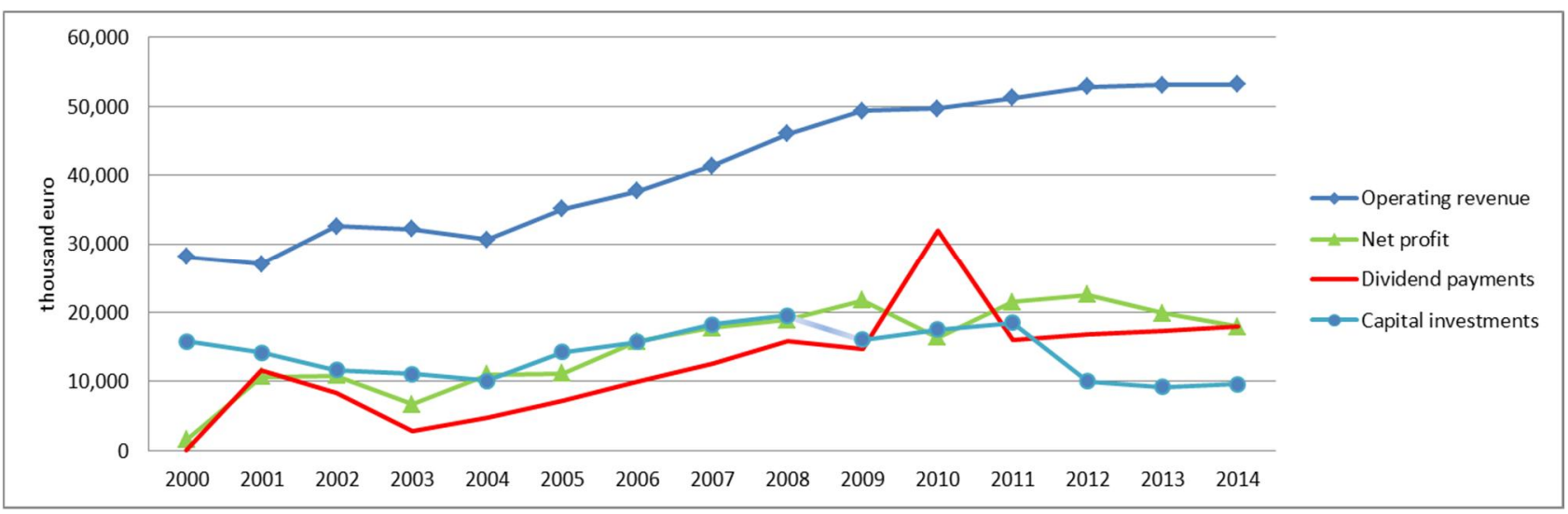

Source: Compiled by the authors based on data from TW's annual reports.

\section{Appendix B. Governance, size, and service characteristics of TW, 2008/ 2009}

\begin{tabular}{|c|c|c|}
\hline & Domain & Feature \\
\hline \multirow{10}{*}{$\begin{array}{l}\frac{8}{0} \\
\frac{c}{0} \\
\frac{5}{0} \\
\frac{0}{0} \\
8 \\
0 \\
\frac{0}{0} \\
\frac{0}{0} \\
\frac{8}{0}\end{array}$} & Ownership & 35.3\% United Utilities (UK) \\
\hline & structure & 34.7\% Tallinn City \\
\hline & & $30.0 \%$ Foreign and local financial investors, free float \\
\hline & & Approximately 1,700 shareholders in total. \\
\hline & \multirow[t]{2}{*}{$\begin{array}{l}\text { Supervisory } \\
\text { board }\end{array}$} & $\begin{array}{l}6 \text { of } 9 \text { members business managers with international experience. The chairman } \\
\text { nominated by United Utilities. Focus on business growth and improvement of } \\
\text { financial results. }\end{array}$ \\
\hline & & $\begin{array}{l}3 \text { of } 9 \text { members from the ruling political party of the City, incl. a deputy mayor. Focus } \\
\text { on advising about political risks. }\end{array}$ \\
\hline & \multirow[t]{4}{*}{ CEO } & Seconded by United Utilities. Expatriated from the parent company. \\
\hline & & Long-term international work experience in water companies. \\
\hline & & Common work history with the chairman of the supervisory board. \\
\hline & & $\begin{array}{l}\text { Working hours, rates of compensation, manner of performance, and all other } \\
\text { matters relating to the employment determined solely by United Utilities. }\end{array}$ \\
\hline \multirow{5}{*}{ 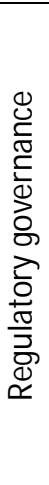 } & \multirow[t]{2}{*}{ Service contract } & $\begin{array}{l}\text { Strict and detailed: includes both water price (formula) and quality-of-service } \\
\text { regulations ( } 97 \text { levels of service). The levels mostly refer to the legislated quality } \\
\text { requirements, such as water quality and pollution concentration loads, but also } \\
\text { water losses, customer service, and sewerage network coverage. }\end{array}$ \\
\hline & & $\begin{array}{l}\text { The exclusivity period prolonged (in 2007) from its initial term of November } 2015 \\
\text { by an extra five years without any competitive tender. }\end{array}$ \\
\hline & \multirow[t]{3}{*}{ Price regulation } & $\begin{array}{l}\text { The price formula: } \mathrm{T} 1=\mathrm{T} 0 \times(1+\Delta \mathrm{CPI}+\mathrm{K}+\text { change of law }) \text {, where } \mathrm{T} 1 \text { stands for the } \\
\text { tariff of the next period and T0 for the tariff in the current period. }\end{array}$ \\
\hline & & No limits set on the allowed rate of return. \\
\hline & & $\begin{array}{l}\text { Price establishment by the City of Tallinn under the price formula from the service } \\
\text { contract. }\end{array}$ \\
\hline \multirow{2}{*}{ 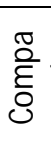 } & $\begin{array}{l}\text { Population } \\
\text { served }\end{array}$ & 405,000 , i.e. approximately $1 / 3$ of the Estonian population. \\
\hline & & erage mains \\
\hline
\end{tabular}




\begin{tabular}{|c|c|c|}
\hline & $\begin{array}{l}\text { Number of } \\
\text { employees }\end{array}$ & 320 \\
\hline \multirow{5}{*}{ 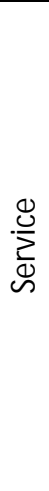 } & $\begin{array}{l}\text { Drinking water } \\
\text { quality }\end{array}$ & $\begin{array}{l}\text { Meets national and EU quality criteria. The highest ever } 98 \% \text { compliance (against } \\
61 \% \text { in } 2001 \text { ) in the network and at the customers' premises. }\end{array}$ \\
\hline & $\begin{array}{l}\text { Wastewater } \\
\text { treatment }\end{array}$ & $\begin{array}{l}\text { Full compliance. In 2006, the Baltic M arine Environment Protection Commission } \\
\text { (HELCOM ) removed Tallinn from its 'hotspots' list as a polluter. The EU EM AS (Eco- } \\
\text { Management and Audit Scheme) certificate in } 2005 .\end{array}$ \\
\hline & Affordability & $\begin{array}{l}\text { Average water bill 1.2-1.3\% of the disposable income of average households. } \\
\text { Water prices increased } 2.2 \text { times between } 2001 \text { and } 2009 \text {. }\end{array}$ \\
\hline & Accessibility & $\begin{array}{l}99.6 \% \text { of the service area covered by the water supply network and } 98 \% \text { by the } \\
\text { public sewerage network. Respective access rates } 98 \% \text { and } 95 \% \text { in } 2001 \text {. }\end{array}$ \\
\hline & $\begin{array}{l}\text { Requirements of } \\
\text { the service } \\
\text { contract }\end{array}$ & Since 2001, either all or 96 out of 97 levels of service annually met. \\
\hline
\end{tabular}

Source: Compiled by the authors based on data from TW's reports and other documents collected. 


\section{Appendix C. Frequency of discursive strategies used for legitimation (+) and de-legitimation (-) by stakeholders}

2008

2009

2010

2011

2012

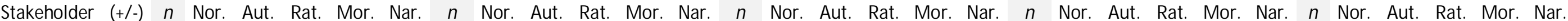

TW

Competition

Authority

$\begin{array}{llllllllll}(+) & 20 & 2 & 6 & 10 & 2 & - & 44 & 11 & 6\end{array}$

(-) 0

Journalists

$(-) \quad 0 \quad-\quad-\quad-\quad-\quad-18$

$\begin{array}{llllll}18 & 6 & 4 & 4 & 3 & 1\end{array}$

19

nor. A

(-1)

(+) 2

$\left(\begin{array}{llllllllllllllllllll}- & 2 & - & - & - & 1 & 1 & 46 & 14 & 1 & 6 & 13 & 12 & 28 & 9 & 2 & 2 & 6 & 9\end{array}\right.$

Politicians

$\begin{array}{llllllllllllllllll}(+) & 14 & 5 & 3 & 5 & - & 1 & 11 & 4 & 0 & 5 & 1 & 1 & 13 & 7 & 2 & 3\end{array}$

$\begin{array}{lllllllllllllllll}(-) & 17 & 4 & 1 & 6 & 4 & 2 & 47 & 10 & 2 & 12 & 11 & 12 & 24 & 13 & 1\end{array}$

\begin{tabular}{lllllllllllllllllll}
$(+)$ & 8 & 8 & - & - & - & - & 6 & 2 & - & 2 & 1 & 1 & 15 & 11 & - \\
\hline
\end{tabular}

Other

$\begin{array}{llllllll}(-) & 16 & 5 & 3 & 3 & 3 & 2 & 39\end{array}$

$\begin{array}{llllllll}15 & 6 & 6 & 7 & 5 & 33 & 18 & 2\end{array}$

\begin{tabular}{|l|l|l}
- & 1 & 4 \\
\hline 2 & 4 & 9 \\
\hline 2 & 1 & 28 \\
\hline 8 & 5 & 26
\end{tabular}

Note. Nor. =normalization, Aut. = authorization, Rat. =rationalization, Mor. =moralization, Nar. =narrativization 